\title{
Effects of the Global Crisis on the Egyptian Textiles and Clothing Sector: A Blessing in Disguise?
}

\begin{abstract}
Amirah El-Haddad
Department of Economics, Faculty of Economics and Political Science, Cairo University, Giza, Egypt

Correspondence should be addressed to Amirah El-Haddad, amirah.elhaddad@feps.edu.eg

Received 24 April 2012; Accepted 23 May 2012

Academic Editors: W. Groot and R. Rasiah

Copyright () 2012 Amirah El-Haddad. This is an open access article distributed under the Creative Commons Attribution License, which permits unrestricted use, distribution, and reproduction in any medium, provided the original work is properly cited.

The textile and clothing (TC) sector has not escaped the slowdown in Egypt in response to the crisis. But it has been in decline since 2001 in response to a changing global environment. Exports, which have been surviving on account of the Qualifying Industrial Zones (QIZ) and Euro-Mediterranean Partnership agreements, have been hit hard by the crisis. Domestic sales are in decline as a result of liberalization, and non-QIZ exporter-unprotected by the agreement-have been turning to the domestic market in competition with non-exporters. If domestic sales continue to decline, without being offset by growth in exports, the industry will continue to decline. To deal with the crisis, short-run mitigation policies can be considered as ensuring banks credit, and paying social insurance for workers in distressed firms. But the sector is suffering from inherent structural problems resulting in high costs. In other words, the crisis has exacerbated the shrinkage of an already struggling industry, so a longer run strategy is needed beyond the crisis response, comprising moving up the clothing industry value chain, conditional export incentives, skills upgrading and undergoing comprehensive institutional reform.
\end{abstract}

\section{Introduction}

Having developed behind protective barriers, the textiles and clothing industry (TC) has been of particular importance to Egypt, notably its contribution to employment, value added, and foreign exchange earnings. In 2008, the industry accounted for 26.4 percent of industrial production, total value added of LE 33.5 billion [1], and close to 10 percent of the country's exports [2]. Finally, textile and clothing enterprises account for a fifth of all industrial sector firms, being the largest single employer with over 400,000 workers, that is almost a quarter of the industrial labor force [3]. The government has long utilized this sector to absorb Egypt's growing labor force and help tackle unemployment problems.

This paper presents the findings from a survey of TC firms and workers collected in September, $2009^{1}$ to assess the effects of the global and financial crisis on this vital sector. The sector has not escaped the slowdown in the Egyptian economy in response to the crisis but it had already been in decline earlier. Can, and should, the sector be helped to weather the current crisis, and/or is it an opportunity to accelerate much needed restructuring of inefficient enterprises?

The paper is divided into five sections. The second highlights the main historical events and circumstances that shaped the TC industry before the crisis. The third briefly describes the survey instrument. Major survey findings about the implications of the crisis, particularly pertaining to social dialogue and employment as well as the restructuring of the sector, are presented in the fourth section of the paper. Finally short, medium- and long-term policy recommendations are discussed in the final section.

\section{Background of the Textiles and Clothing Industry before the Crisis}

2.1. Production under Protection. The history of Egyptian textiles falls into two periods: protectionism from the thirties to the seventies and gradual liberalization thereafter. During the 1930s and 1940s, the production of cotton textiles was increasing at a modest rate, growing more rapidly in the following two decades. Exports, mainly cotton yarns and 
TABLE 1: Public sector share in TC production $(1997,2006)$.

\begin{tabular}{lcc}
\hline & 1997 & 2006 \\
\hline Cotton ginning and pressing & $87 \%$ & $73 \%$ \\
Manufacture of textiles except cotton ginning and pressing** & $43 \%$ & $31 \%$ \\
Manufacture of wearing apparel; dressing and dyeing of fur*** & $18 \%$ & $0 \%$ \\
Gross TC public sector production & $39 \%$ & $22 \%$ \\
\hline
\end{tabular}

Source: Author's calculation based on central agency for public mobilization and statistics (CAPMAS), annual statistical book, various issues. * Original data are available for fiscal years. Calendar years are used as an approximation. Year 1997, for example, is originally 1996/1997, where the fiscal year runs from July 1st to June 30th. ${ }^{* *}$ International Standard Industrial Classification (ISIC) Revision 3 code $17 .{ }^{* * *}$ ISIC code 18.

fabrics, were directed to the Eastern European Bloc through bilateral barter agreements [7-9].

Growth was maintained throughout the nineteen seventies, as part of Egypt's public-sector-led, inward-looking import substitution development strategy (1952-1971) based on centralized ownership and a command economy. Most notable was the tight control of the cotton market for over twenty years. Until the late nineteen eighties, the government-run textile industry was the sole purchaser of Egyptian cotton. Much of what was purchased was generally secured at lower than international prices, to be spun by local mills, in order to be used in the production of largely subsidized fabrics and clothes sold at "social prices" 2 [10, $11]^{3}$. This fact, along with the protection of the clothing industry, contributed to a massive misallocation of Egyptian high quality cotton ${ }^{4}$, which was wasted on the production of low-quality fabrics and clothing. The inefficiency in allocation on account of distorted market signals and direct government control persisted for years: the few clothing exporting firms resorted to producing their own fabrics to attain the required quality $[12,13]^{5}$.

2.2. Liberalization and Privatization under the ERSAP. The industry began to change with the reversal of the state-led development strategy beginning with the open door policy in the early 1970s, but more so in the early 1980s when the government terminated the earlier subsidy to clothing sold to the mass domestic market, which represented about 80 percent of public sector weaving companies' production [17]. In addition, cotton trade was liberalized in 1994 as part of the Economic Reform and Structural Adjustment Program (ERSAP) of 1991. These two events have created problems for the industry, namely, a rise in production costs due to the price rise of cotton. Furthermore, combined with continued protection of the clothing industry, liberalization of cotton trade created a structural setting whereby an increasing share of Egyptian cotton has been exported (especially in the form of lint) rather than entering into the country's own clothing value added chain, a situation which left domestic mills idle. Italy and Japan were the major importers of Egyptian cotton up until 2002. More recently, Asian manufacturers, India, Pakistan, and South Korea, have taken this position $[11]^{6}$. At the same time, after the collapse of the Soviet Union, exports of textiles and textile articles fell from nearly 50 percent of Egypt's total export earnings during the 1950 s to the 1970 s to 33 per cent in 1991-92 [7].
On the other hand, the pace of privatization has been very slow. Public, vertically integrated, large-size firms dominated the manufacture of the textile group over a long period of time, their share slowly shrinking in favor of the private sector. In 2006, the public sector accounted for 73 percent of cotton ginning and pressing and for 31 percent of fabric production and a negligible amount of garment production. This trend has halved the public sector's share in TC from 39 percent in 1997 to about 20 percent in 2006 (Table 1). Currently, there is just one holding company, the Holding Company for Spinning, Weaving, Cotton and Ready-made Garments, with 33 affiliated public companies ${ }^{7,8}$. However, the privatization program ${ }^{9}$ and the general neglect for these companies by the government have resulted in a scaling down of publicly owned textile companies which has not been offset by comparable growth of private companies [18].

\subsection{The Changing Global Environment: Egypt's Accession to} WTO and the End of the Multi-Fibre Agreement (MFA). Two more major events have shaped the current status and structure of the Egyptian TC industry, namely, Egypt's accession to the WTO in 1995 and the end of the Multi-Fibre Agreement a decade later.

Egypt's accession to the WTO initiated further liberalization of the sector. Egypt lifted a 30-year import ban on TC in 1998 for textiles and in 2002 for clothing, both in compliance with its WTO commitments. Nevertheless, the ban was initially replaced by prohibitive tariffs ${ }^{10}$. Only later-in 2000, 2004, and 2007-were substantial tariff reductions introduced [19]. Currently, most favored nation rates (MFN) are 0-5 percent on yarns, 0-10 percent on fabrics, and generally in the neighbourhood of 30 percent on carpets and other textile floor coverings, clothes, and home textiles [19]. Indeed, in most cases, these rates are below their WTO-bound rates. The phase-out of the Multi-Fibre Agreement has gradually subjected textiles and clothing to normal WTO rules. Hence exporters have faced increased competition from previously quota constrained, more competitive countries.

2.4. Precrisis Trends. Successive tariff reductions, the phasing out of the MFA, and the downsizing of public sector firms have jointly driven the trends shown in Figure 1. Most remarkable has been a sharp decline in the production of TC since the year 2000. In 2004, production fell to its lowest value since 1997 to only 60 percent its value 4 years earlier, 
TABLE 2: TC production, imports, and exports (2000-2008).

\begin{tabular}{|c|c|c|c|c|}
\hline & 2000 & 2004 & 2007 & 2008 \\
\hline \multicolumn{5}{|l|}{ Level (US\$ millions) } \\
\hline TC production & 7659 & 4900 & 6520 & \#N/A \\
\hline TC exports & 1435 & 1768 & 2489 & 2634 \\
\hline TC imports & 807 & 1365 & 2595 & 4642 \\
\hline \multicolumn{5}{|l|}{ Growth rate (\%) } \\
\hline TC production & & $-36 \%$ & $33 \%$ & \#N/A \\
\hline TC exports & & $23 \%$ & $41 \%$ & $6 \%$ \\
\hline TC imports & & $69 \%$ & $90 \%$ & $79 \%$ \\
\hline Ratio of imports to exports & 0.6 & 0.8 & 1.0 & 1.8 \\
\hline
\end{tabular}

Source: Production: IDA [4]; same note as in Figure 1.

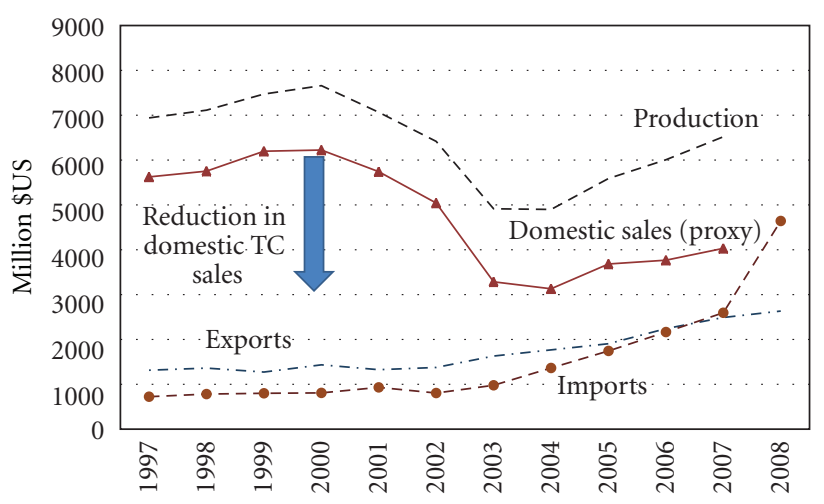

FIGURE 1: TC Evolution (1997-2008). Source: Production: IDA [4]; Exports and Imports: International Trade Center [21]. Data based on the partner reported data (mirror data). Note: data are only for companies registered at IDA. Each registered company updates its data at IDA every 5 years, which explains why for some categories values of indicators remain unchanged from one year to the other.

falling from just under $\$ 8$ billion in 2000 to around $\$ 5$ billion in 2004. As a result of tariff reductions, the country has experienced a surge of imported textiles and clothing after 2002 and again after 2007 (Figure 1).

Egyptian producers are unable to compete with lower cost overseas producers, especially those in China, losing market share at home, shown by the dramatic decline in domestic TC sales. Domestic producers' sales have halved in the four years between 2000 and 2004 falling from $\$ 6$ billion to $\$ 3$ billion reflecting the fact that foreign competitors are driving Egyptian TC firms out of the domestic market ${ }^{11}, 12$. The substantial growth of TC imports is not the sole cause for production and domestic sale decline, there is also the effects of privatization and government's neglect of public spinning and weaving companies ${ }^{13}$.

The end of the quota system since January 2005 could have had severe consequences for Egypt's ability to penetrate export markets, since the country is brought into direct competition with China, India, Pakistan, Bangladesh, Indonesia, and even Turkey, which were quota constrained under the former MFA. But the effects have been moderated by the Qualifying Industrial Zone (QIZ) protocol (December, 2004) with the US and Israel, and by the Euro-Mediterranean Partnership agreement (as of 2005) with the European Union (EU) both of which allow Egyptian textile products dutyand quota-free access to these markets conditional on rules of origin ${ }^{14}$. Hence Egypt is benefiting from the fact that other previous beneficiaries of the MFA are losing market share. These two markets account for more than three quarters of all TC exports.

TC exports have been growing rapidly: by 23 percent during 2000-2004 as input prices fell following yarn and fabric tariff reductions and double that growth rate (41 percent) between 2004 and 2007 on account of these major agreements (Table 2, see also Figure 1). Egyptian export market shares have remained more or less stable between the two periods 1995-2004 and 2005-2007 in response to quota termination with the minor exceptions of cotton exports (chapter 52) and carpets and other floor coverings (chapter $57)^{15}$.

But as shown by Figure 1, imports have been massively growing since 2000 reaching a growth rate of about 80 percent in just one year, between 2007 and 2008 (Table 2). Whilst in 2000 the value of imports was half that for exports (0.6), by 2008 it has nearly doubled (1.8). The industry has become a drain on Egypt's foreign exchange resources rather than the earner the country has been counting on. Since the substantial increase in imports has not been matched by an equal rise in exports, the obvious result is a negative overall trade balance (Figure 2), for which the textiles sector (as opposed to clothing) is largely to blame. But it is the clothing sector, which imports textiles as inputs for its production. This is because products of the sector's supporting industries (mainly textiles but also dyeing and printing) are not at the required standards ${ }^{16}$. Yet that is to be expected since tariffs on clothing, despite the large reductions, are still relatively high compared to those on textiles. Thus, with further tariff reductions a similar effect on the clothing trade balance can be expected.

2.5. Egypt's Unfavorable Cost Structure. Why are Egyptian producers losing domestic market share? Why are the sector's imports double its exports? The sector is "relatively" uncompetitive. The lack of competitiveness arises from 


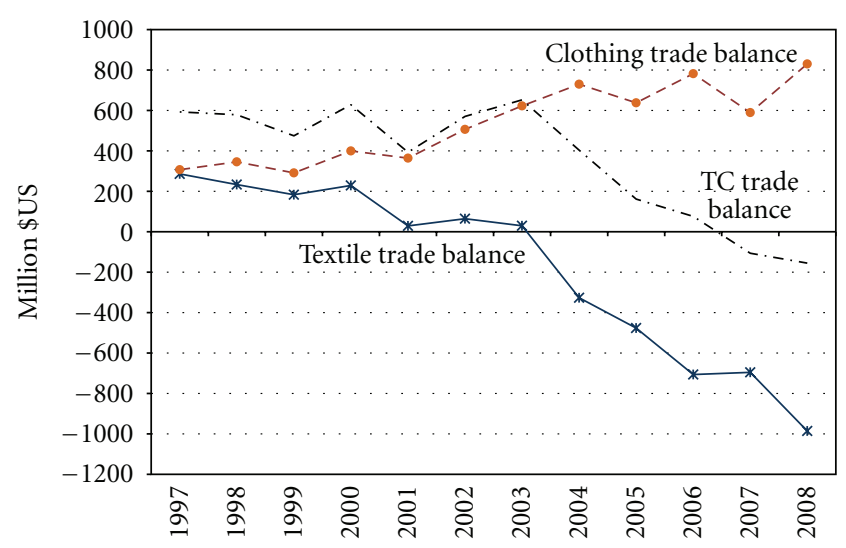

Figure 2: TC Trade Balance (Exports minus Imports, 1997-2008). Source: International Trade Center [21]. Data is based on the partner reported data (Mirror data).

TABLE 3: Unfavorable cost structure: labor cost.

\begin{tabular}{lcc}
\hline & Wage per hour in US\$ & Equivalent to LE \\
\hline Egypt & 0.82 & 4.5 \\
China (mainland) & 0.48 & 2.6 \\
Sri Lanka & 0.46 & 2.0 \\
Pakistan & 0.37 & 1.5 \\
Bangladesh & 0.28 & 1.5 \\
Vietnam & 0.28 & 1.5 \\
\hline
\end{tabular}

Source: Adapted from World Bank [5]. Exchange rate used is LE 5.5 to the \$.

several sources, which can be divided into production or direct costs and transaction cost.

\subsubsection{Production Cost Structure of the Industry}

Labor. Private firms have been opening up since liberalization and are more likely to be exporters. But the country's cost structure is not favorable. Wage costs, which account for about 30 percent of a garment's FOB price, are higher than in competitor countries (Table 3), whilst productivity is lower. As a middle-income country, costs per operator hour in Egypt (\$0.82) are above one and a half times those in mainland China (\$0.48) and Sri Lanka (\$0.46), and about three times those in Vietnam and Bangladesh $(\$ 0.28)$.

Despite greater flexibility around employment practices such as the facilitation of the firing process afforded by the unified labor law of $2003^{17}$, some still argue that labor practices are not flexible enough, for example, firing costs are high, at an average 132 weeks of wages [23]. Moreover, working hours are short. In fact, Egypt has the fewest firm operating days per year compared to a group of 20 competitors: 281 compared to for example, 351 days in Pakistan [5].

Other Direct Inputs. Second is the inefficiency of the stateowned sector. Having enjoyed high levels of protection, firms in this sector produce high-cost, low-quality products. Continued public sector dominance of the spinning and weaving industry limited the extent to which producers were responsive to consumer preferences and burdened that sector with overemployment, inferior technology, operational inefficiencies, and low levels of capital utilization. Substantial public investments have not been made in the spinning and weaving sector for many years. For example, most machinery used by public sector firms is more than 15 years old [24].

As a result of these distortions and inefficiencies, other direct costs such as fabric costs are also relatively higher for Egypt than any of its competitors [5], which is the reason why most inputs of fabrics are imported rather than produced internally. The sector's productivity is amongst the lowest in Egypt: productivity per Egyptian pound is LE 10 compared to LE 73 for manufacture of coke, refined petroleum products, and nuclear fuel (Figure 3 ). With respect to other direct input costs, Egypt has a relatively high power outage rate (reported at 17 days a year in 2004) compared to 3 days only in Turkey and 7 in Romania. In fact, power outages result in 1-5 percent losses of total sales for 70 percent of Egyptian firms [5].

Transaction Costs of the Industry. Three factors have eased transaction costs in Egypt: (1) recent Ministry of Finance reforms facilitating and streamlining customs and investment ${ }^{18}$ procedures, (2) the large investments in Egyptian ports, and (3) the general trend for mega carriers and international ship owners to serve Mediterranean ports. This has in turn set a downward pressure on prices. The World Bank [5] reports that prices have halved during the last five years in eastern Mediterranean locations and were reduced by a third in western ones. As a result, Egypt's rank in the trading across borders indicator of the Doing Business Report [25] has been favorable: 24 out of 181 countries and 4th of all 24 Arab Countries.

Nevertheless, private companies still face high transaction costs, through lengthy import and export procedures, customs and low port transparency and inefficiencies, handling costs and port charges, and other nontariff barriers (NTBs). For example, handling costs are higher in the port of Alexandria than in Haifa, Israel, or even Izmir, Turkey. Port charges are also higher in Alexandria than Turkey [5, 26]. Poor port services stem from low traffic volumes and poor port management in addition to an inadequate regulatory framework. More recently, Egypt ranks 131 and 114 of 133 countries in terms of tariff barriers and prevalence of trade barriers, respectively [27].

Additionally, formal channels for dispute resolution mechanisms between firms in the industry are limited and inefficient [28]. Other competitiveness indicators of the Egyptian business environment have also been low. Egypt's overall ranking in the more recent 2009 Doing Business Report is 106 out of 183 economies [23]; on a number of subindicators Egypt's performance is far below other MENA countries.

\section{A Note on the Survey}

Two new data sets-a firm questionnaire covering 275 TC firms and a worker questionnaire covering 5,383 TC 


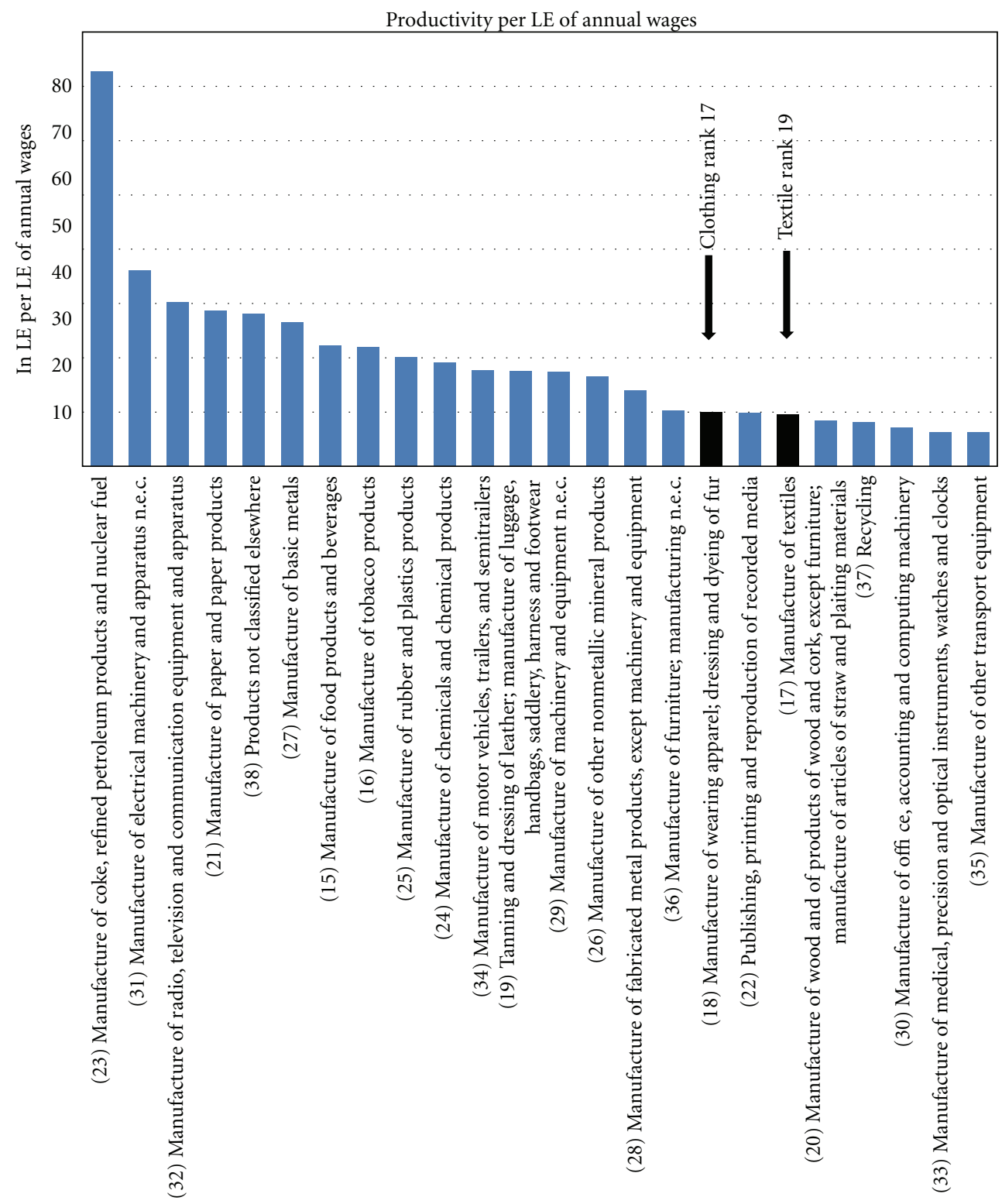

FIGURE 3: Labor productivity for manufacturing activities: given in Egyptian pounds for each pound spent in annual wages. Source: CAPMAS [29].

workers-were collected in September, 2009. The following two sections briefly describe the questionnaires and sampling design.

3.1. Firm Level Survey. The firm survey comprised six modules: basic firm data, firm activity, production, sales, exports and employment; trends after the crisis; job opportunities, and future plans. Table 1 gives a breakdown of sampled firms.

Firms were sampled based on a combination of two sample frames provided by the Egyptian Federation of Industries ${ }^{19}$. Unfortunately, the final frame does not reflect the true number of firms in the TC industry in Egypt. There simply is not any comprehensive, accurate and detailed frame that includes basic firm level data to ensure a representative sample $^{20}$. The 275 firms covered the governorates of Greater
Cairo, Alexandria, and El-Sharkyia; these three include more than 90 percent of Egypt's TC firms. Greater Cairo comprises the governorates of Cairo, Giza, 6th of October, Helwan, and El-Qalyubia.

Stratified sampling was used to ensure sufficient large sized and exporting firms. The resulting geographical distribution of sampled firms was very similar to that in the sample frame (Table 4). Tables 5 and 6 give a breakdown of sampled firms by activity, market orientation, ownership, and firm size.

3.2. Worker Survey. The worker questionnaire was divided into five modules: basic characteristics, work conditions, skills and training, job satisfaction; and crisis effects. The sample was stratified by four size categories: less than 
TABLE 4: Sample firm distribution by location.

\begin{tabular}{lcccc}
\hline & & No. and \% of firms in the sample & \multicolumn{2}{c}{ No. and \% of firms in sample frame } \\
\hline Greater Cairo & 181 & $66 \%$ & 820 & $70 \%$ \\
Alexandria & 60 & $22 \%$ & 253 & $22 \%$ \\
El-Sharkyia & 34 & $12 \%$ & 99 & $8 \%$ \\
\hline
\end{tabular}

Source: Author's calculation based on Egyptian federation of industries sample frame and IDSC sampling design.

TABLE 5: Sample firm distribution by activity, market orientation, and ownership.

\begin{tabular}{|c|c|c|c|c|c|c|c|c|}
\hline & \multicolumn{2}{|c|}{ Activity } & \multicolumn{3}{|c|}{ Market orientation } & \multicolumn{2}{|c|}{ Ownership } & \multirow[t]{3}{*}{ Total } \\
\hline & \multirow[t]{2}{*}{ Textiles } & \multirow[t]{2}{*}{ Clothing } & \multicolumn{2}{|c|}{ Exporting } & \multirow[t]{2}{*}{ Nonexporting } & \multirow[t]{2}{*}{ Public sector } & \multirow[t]{2}{*}{ Private sector } & \\
\hline & & & QIZ & Non-QIZ & & & & \\
\hline No. of firms & 97 & 178 & 53 & 40 & 182 & 6 & 169 & 275 \\
\hline$\%$ & $35 \%$ & $65 \%$ & $19 \%$ & $15 \%$ & $66 \%$ & $2 \%$ & $98 \%$ & $100 \%$ \\
\hline
\end{tabular}

Source: IDSC TC firm questionnaire [6].

TABLE 6: Sample firm distribution by firm size*.

\begin{tabular}{|c|c|c|c|c|}
\hline & Small & Medium & Large & Total \\
\hline No. of firms in the sample & 125 & 115 & 35 & 275 \\
\hline$\%$ & $45 \%$ & $42 \%$ & $13 \%$ & $100 \%$ \\
\hline Share in real weighted production & $5 \%$ & $10 \%$ & $85 \%$ & $100 \%$ \\
\hline
\end{tabular}

Source: IDSC TC firm questionnaire [6]. *Small firms: up to 50 workers, medium: greater than 50 and up to 500 workers, and large: over 500 workers.

TABLE 7: Sample worker distribution.

\begin{tabular}{lccc}
\hline Firm category (no. of workers) & No. of sampled firms (1) & $\begin{array}{c}\text { No. of workers sampled from } \\
\text { each firm in category (2) }\end{array}$ & $\begin{array}{c}\text { No. of sampled workers in } \\
\text { category }(3)=(1) *(2)\end{array}$ \\
\hline Less than 10 & 100 & 5 & 500 \\
$10-100$ & 101 & 20 & 2020 \\
Greater than $100-1000$ & 63 & 40 & 2520 \\
More than 1000 & 11 & 50 & 550 \\
\hline Total & 275 & & 5590 \\
\hline
\end{tabular}

Source: IDSC worker survey sampling note [14].

10 workers, from 10 to 100 , from 100 to 1000 , and larger than 1000 workers (Table 7); 5,590 workers were to be surveyed however, due to practical problems in the field, only 5383 questionnaires were completed.

\section{Survey Results: Effects of the Crisis}

4.1. Production, Sales, and Exports by Activity, Ownership, Market Orientation, and Firm Size. There was a substantial decline in production, domestic sales, and exports between 2008 and 2009 (21 percent, 16 percent, and 22 percent, resp., Table 8$)$. Sales have already been declining since the year before ( -16 percent in the year 2008), most likely on account of the 2007 tariff reductions that allowed imports to capture a substantial part of the domestic market. Exports have been declining steadily since 2006, with an accelerated decline in the year of the crisis. This steady decline can be attributed to both the end of the MFA and weakening public sector export performance.
Both textiles and clothing have been hit by the crisis (Table 9). For exports the fall has been largest in textiles ${ }^{21}$, falling by 46 percent, an absolute loss of LE 147 million amongst the sampled firms. But the decline in production is more pronounced in the clothing sector.

Amongst exporters, production in QIZ firms has fallen by one third, driven by sharp declines in both domestic sales and exports (Table 9). These firms have lost half their domestic market ( -49 percent) and a quarter of their export market ( -24 percent). Non-QIZ firms have been also losing a substantial part of their export market ( -18 percent), but these firms have increased their sales in the domestic market by 9 percent, quite likely in an attempt to counteract their export market losses. Non-exporting firms have lost 8 percent of their domestic market between the two years, which corresponds to a 5 percent decline in production.

Both large and small firms have experienced substantial declines. Small firms (less than 50 workers) have lost a substantial part of their domestic market ( -35 percent), 
TABLE 8: Sample estimates for production, sales, and exports (2004-2009).

\begin{tabular}{|c|c|c|c|c|c|c|}
\hline & 2004 & 2005 & 2006 & 2007 & 2008 & 2009 \\
\hline \multicolumn{7}{|c|}{ Level (LE millions) for 265 firms* } \\
\hline Real production & 2511 & 2263 & 2298 & 2099 & 2034 & 1604 \\
\hline Real sales & 1183 & 1158 & 1132 & 1203 & 1011 & 854 \\
\hline Real exports & 1038 & 1013 & 1164 & 1081 & 970 & 755 \\
\hline \multicolumn{7}{|l|}{ Growth rate $(\%)$} \\
\hline Real production & & $-10 \%$ & $2 \%$ & $-9 \%$ & $-3 \%$ & $-21 \%$ \\
\hline Real sales & & $-2 \%$ & $-2 \%$ & $6 \%$ & $-16 \%$ & $-16 \%$ \\
\hline Real exports & & $-2 \%$ & $15 \%$ & $-7 \%$ & $-10 \%$ & $-22 \%$ \\
\hline
\end{tabular}

Source: Author's calculations based on IDSC firm questionnaire data [6]. ${ }^{*}$ Note: these figures are calculated using sampling weights for all surveyed firms after dropping firms with missing observations. Firms that opened up after 2004 are also excluded from the analysis. Figures converted from nominal to real using CPI from world development indicators [15] and IMF financial statistics [16] $(n=265)$.

TABLE 9: Sample estimates for production, sales, and exports by activity and market orientation (2008-2009).

\begin{tabular}{|c|c|c|c|c|c|c|c|c|c|c|c|c|}
\hline & \multicolumn{4}{|c|}{ Activity } & \multicolumn{6}{|c|}{ Market orientation } & & \\
\hline & \multicolumn{2}{|c|}{ Textile } & \multicolumn{2}{|c|}{ Clothing } & \multicolumn{4}{|c|}{ Exporting } & \multicolumn{2}{|c|}{ Non-exporting } & \multicolumn{2}{|c|}{ Total } \\
\hline & & & & & \multicolumn{2}{|c|}{ QIZ } & \multicolumn{2}{|c|}{ Non-QIZ } & & & & \\
\hline & 2008 & 2009 & 2008 & 2009 & 2008 & 2009 & 2008 & 2009 & 2008 & 2009 & 2008 & 2009 \\
\hline \multicolumn{13}{|l|}{ Level (LE millions) } \\
\hline Real production & 1135 & 938 & 899 & 666 & 1096 & 733 & 593 & 545 & 345 & 326 & 2034 & 1604 \\
\hline Real sales & 794 & 651 & 217 & 203 & 323 & 164 & 349 & 381 & 339 & 310 & 1011 & 854 \\
\hline Real exports & 321 & 174 & 649 & 581 & 716 & 547 & 253 & 208 & 0 & 0 & 970 & 755 \\
\hline \multicolumn{13}{|c|}{ Growth rate 2008-2009 (\%) } \\
\hline Real production & \multicolumn{2}{|c|}{$-17 \%$} & \multicolumn{2}{|c|}{$-26 \%$} & \multicolumn{2}{|c|}{$-33 \%$} & \multicolumn{2}{|c|}{$-8 \%$} & \multicolumn{2}{|c|}{$-5 \%$} & \multicolumn{2}{|c|}{$-21 \%$} \\
\hline Real sales & \multicolumn{2}{|c|}{$-18 \%$} & \multicolumn{2}{|c|}{$-6 \%$} & \multicolumn{2}{|c|}{$-49 \%$} & \multicolumn{2}{|c|}{$9 \%$} & \multicolumn{2}{|c|}{$-8 \%$} & \multicolumn{2}{|c|}{$-16 \%$} \\
\hline Real exports & \multicolumn{2}{|c|}{$-46 \%$} & \multicolumn{2}{|c|}{$-10 \%$} & \multicolumn{2}{|c|}{$-24 \%$} & \multicolumn{2}{|c|}{$-18 \%$} & \multicolumn{2}{|c|}{$0 \%$} & \multicolumn{2}{|c|}{$-22 \%$} \\
\hline
\end{tabular}

Source: Author's calculations based on IDSC firm questionnaire data [6]; same note as Table 8 above.

TABLE 10: Sample estimates for production, sales, and exports by firm size and ownership (2008-2009).

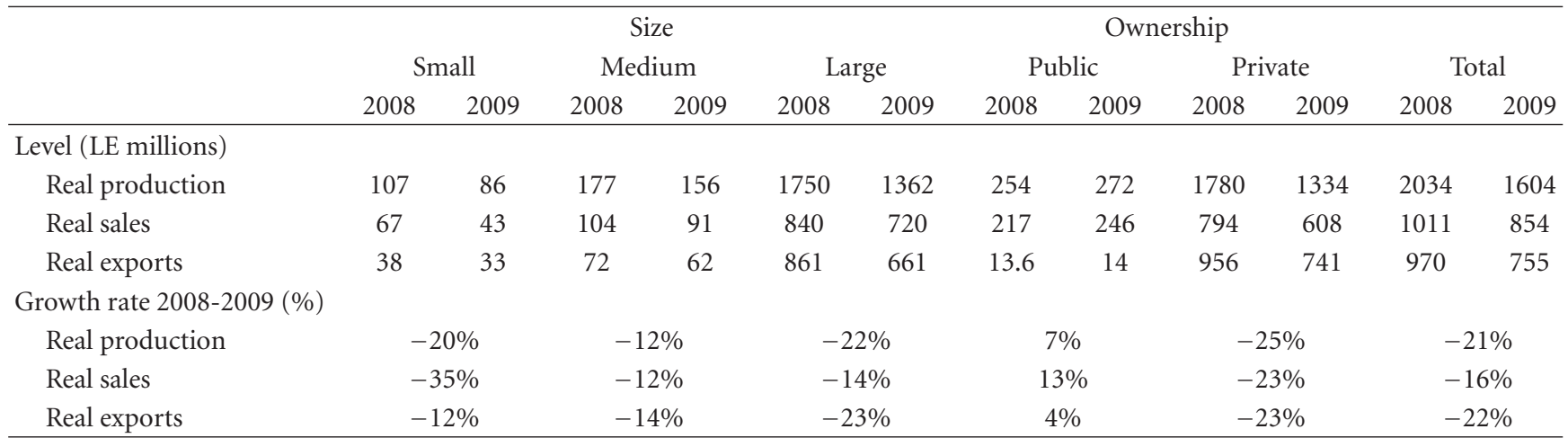

Source: Author's calculations based on IDSC firm questionnaire data [6]; same note as Table 8 above.

though production has only fallen by 20 percent (Table 10). About half the small-sized firms stated they accumulated inventories in response to the crisis. Medium and large firms had smaller declines in sales than small firms. For medium firms production fell by the same as sales, and rather more than sales in the case of large firms.

The declines in production, domestic market sales and exports in the year of the crisis have mainly been concentrated in the private sector (Table 10), which lost about a quarter of the size of both of its markets: domestic and export. Production has followed these declines very closely. The public sector, however, seems to be relatively flourishing in the crisis years, which appears surprising given the steady decline of that sector. However, this positive trend reflects the performance of just one of the six public sector firms in the sample. The other five firms have experienced sharp contractions. Without this single firm, reductions in public sector production, sales, and exports would be more pronounced in the sample. Table 11 gives public sector sample estimates during the year of 
TABLE 11: Sample estimates for production, sales, and exports by ownership (2008-2009) without public sector outlier (firm \# 136).

\begin{tabular}{|c|c|c|c|c|c|c|}
\hline & \multicolumn{2}{|c|}{ Public } & \multicolumn{2}{|c|}{ Private } & \multicolumn{2}{|c|}{ Total } \\
\hline & 2008 & 2009 & 2008 & 2009 & 2008 & 2009 \\
\hline \multicolumn{7}{|l|}{ Level (LE millions) } \\
\hline Real production & 83 & 63 & 1780 & 1331 & 1863 & 1397 \\
\hline Real sales & 49 & 41 & 794 & 608 & 1011 & 650 \\
\hline Real exports & 10 & 9 & 956 & 741 & 970 & 750 \\
\hline \multicolumn{7}{|c|}{ Growth rate 2008-2009 (\%) } \\
\hline Real production & \multicolumn{2}{|c|}{$-24 \%$} & \multicolumn{2}{|c|}{$-25 \%$} & \multicolumn{2}{|c|}{$-25 \%$} \\
\hline Real sales & \multicolumn{2}{|c|}{$-16 \%$} & \multicolumn{2}{|c|}{$-23 \%$} & \multicolumn{2}{|c|}{$-23 \%$} \\
\hline Real exports & \multicolumn{2}{|c|}{$-8 \%$} & \multicolumn{2}{|c|}{$-23 \%$} & \multicolumn{2}{|c|}{$-22 \%$} \\
\hline
\end{tabular}

Source: Author's calculations based on IDSC firm questionnaire data [6]; same note as Table 8 above.

TABLE 12: Public sector sample estimates excluding outlier for production, sales, and exports (2004-2009).

\begin{tabular}{|c|c|c|c|c|c|c|}
\hline & 2004 & 2005 & 2006 & 2007 & 2008 & 2009 \\
\hline \multicolumn{7}{|l|}{ Level (LE millions)* } \\
\hline Real production & 128 & 144 & 123 & 107 & 83 & 63 \\
\hline Real sales & 51 & 90 & 73 & 67 & 49 & 41 \\
\hline Real exports & 21 & 20 & 17 & 14 & 10 & 9 \\
\hline \multicolumn{7}{|l|}{ Growth rate $(\%)$} \\
\hline Real production & & $12 \%$ & $-15 \%$ & $-13 \%$ & $-22 \%$ & $-24 \%$ \\
\hline Real sales & & $77 \%$ & $-18 \%$ & $-9 \%$ & $-26 \%$ & $-16 \%$ \\
\hline Real exports & & $-3 \%$ & $-13 \%$ & $-18 \%$ & $-30 \%$ & $-8 \%$ \\
\hline
\end{tabular}

Source: Author's calculations based on IDSC firm questionnaire data [6]. * Note: these figures are calculated using sampling weights for all 5 public sector firms excluding the outlier. Figures converted from nominal to real using CPI from World Development Indicators [15] and IMF Financial Statistics [16] $(n=5)$.

TABLe 13: Private sector sample estimates for production, sales, and exports (2004-2009).

\begin{tabular}{|c|c|c|c|c|c|c|}
\hline & 2004 & 2005 & 2006 & 2007 & 2008 & 2009 \\
\hline \multicolumn{7}{|l|}{ Level (LE millions)* } \\
\hline Real production & 2372 & 2100 & 2147 & 1857 & 1780 & 1334 \\
\hline Real sales & 1122 & 1050 & 1030 & 1003 & 794 & 608 \\
\hline Real exports & 1017 & 993 & 1146 & 747 & 956 & 741 \\
\hline \multicolumn{7}{|l|}{ Growth rate (\%) } \\
\hline Real production & & $-11 \%$ & $2 \%$ & $-14 \%$ & $-4 \%$ & $-25 \%$ \\
\hline Real sales & & $-6 \%$ & $-2 \%$ & $-3 \%$ & $-21 \%$ & $-23 \%$ \\
\hline Real exports & & $-2 \%$ & $15 \%$ & $-35 \%$ & $28 \%$ & $-23 \%$ \\
\hline
\end{tabular}

Source: Author's calculations based on IDSC firm questionnaire data [6]. ${ }^{*}$ Note: these figures are calculated using sampling weights after dropping firms with missing observations. Firms that opened up after 2004 are also excluded from the analysis. Figures converted from nominal to real using CPI from World Development Indicators [15] and IMF Financial Statistics [16] $(n=259)$.

the crisis without this firm's data. It is evident that public production has also contracted by a quarter, also triggered by significant declines in export and domestic market sales.

4.1.1. Which Results Are Driven by the Crisis? In order to be able to judge the extent to which the crisis has contributed to the decline in the year 2009, we need to follow the sample back a few years. According to the sample, the sector has been steadily shrinking since 2006 (Tables 8, 12 and 13). The decline of the public sector is driven by spinning firms' reduced demand of ginning firms' cotton yarns [17] and consequently their own production. Long staple cotton prices have increased relative to the demand on spinning and weaving firms' products. Reduced demand for fine yarns and high end products has also reduced local spinning and weaving companies' consumption of Egyptian cotton. For these companies, imported cheap short-staple cottons have replaced long ones. As a result, total consumption of local spinning and weaving firms during Jan-July 2009 amounted to 38 thousand tons which is the lowest consumption of Egyptian cotton in 70 years. In addition to that is the termination of public investments to that sector. These factors have resulted in halts in production in several public sector cotton ginning, and spinning and weaving companies [17]. Thus, it is likely that for the public sector negative 
TABLE 14: Sample job losses by gender and employee formality status (2007-2009).

\begin{tabular}{|c|c|c|c|c|c|}
\hline & Formal & Informal & Females & Males & Total \\
\hline Job losses & 1,464 & 202 & 721 & 945 & 1,666 \\
\hline Share in job losses & $88 \%$ & $12 \%$ & $43 \%$ & $57 \%$ & $100 \%$ \\
\hline \% Change in employment 2007-2009 & $-2.9 \%$ & $-10 \%$ & $-3.4 \%$ & $-2.98 \%$ & $-3.2 \%$ \\
\hline Total sample employment in 2007 & 50711 & 2112 & 21148 & 31675 & 52823 \\
\hline Share in total employment in 2007 & $96 \%$ & $4 \%$ & $40 \%$ & $60 \%$ & $100 \%$ \\
\hline
\end{tabular}

Source: Author's calculation based on firm questionnaire [6] using sampling weights.

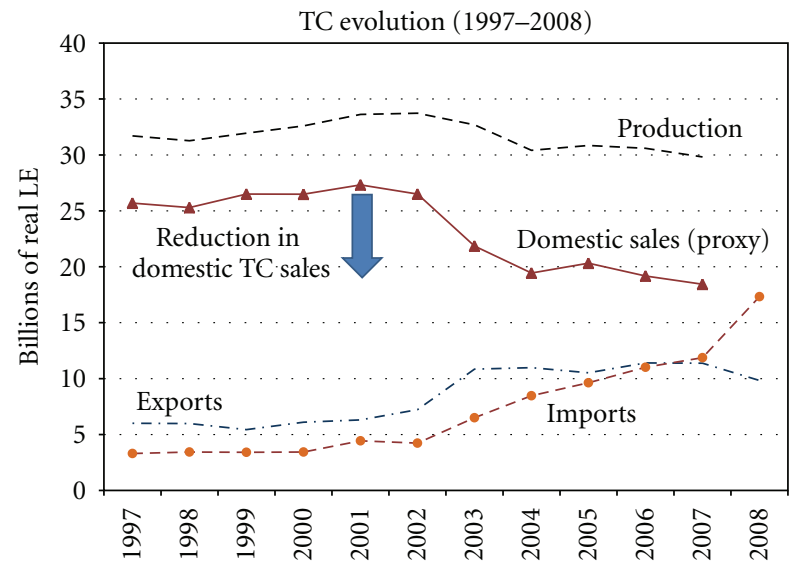

Figure 4: TC Evolution (1997-2008): In Real Terms. Source: Same as Figure 1. Figures converted from nominal to real using CPI from World Development Indicators [15] and IMF Financial Statistics [16].

growth rates are not the result of the crisis (notice the negative trends since 2006).

In contrast, export demand has substantially dropped for the private sector due to the crisis (Table 13). In fact, the private sector experienced substantial growth in exports in 2008 after a dip in 2007. Exports have likely picked up in 2008 due to the 2007 tariff reductions, which allowed cheaper imported inputs thus more exports. The crisis has unfortunately reversed this momentum for the private sector. This is so whilst domestic market sales have been falling already since 2005 for the private sector and since 2006 for public firms, due to increased competition from imported TC products (compare to Table 8 ).

In summary, it is likely that shrinkage in the public sector has little to do with the crisis. For the private sector, however, shrinkages in domestic sales are largely independent of the crisis whilst those in exports are directly triggered by it.

\subsubsection{Reconciliation of Survey Data with Secondary Data:} Nominal and Real. Tables 8, 12, and 13 above show negative growth rates for domestic sales and production. But Figure 1 indicates increases in exports, domestic sales, and so production since around 2004 (the precise year differing by series). This apparent discrepancy is reconciled by ensuring all the data are reported in real terms, which the survey data already are. Figure 4 reports the same data as Figure 1, but converted to real Egyptian pounds. The trends in the two sets of data are now similar. There has been a declining trend in sales since 2001 and in production since 2002; this trend has not recovered as yet. Exports have risen in 2003 with the January devaluation of that year but have more or less remained steady since. If domestic sales continue to decline at this rate, without any offsetting increase from higher exports, then the industry will continue to decline. Other sources have reported the same declining trend: between the early 1980 s and 2005 the share of TC in manufacturing value added fell by 10 percent, the employment share by 7 percent, and that for investment by 15 percent [30].

\subsection{Employment and Industry Restructuring}

4.2.1. Substantial Job Losses. There has been a 3.2 percent decline in employment amongst firms in the sample (Table 14), that is, 1,666 job losses throughout sampled firms. Relatively speaking, women (decline of 3.4 percent between 2007 and 2009), informal employees ${ }^{22}$ (decline by 10 percent), and low skilled and least educated workers have been the hardest hit. Eighty-one percent of the firms who reported laying off workers indicated that those laid off are illiterates and those who could just about read and write. But in absolute terms, the decline has been greatest amongst formal employees (1,464 losses versus 202 for informally employed workers).

All job losses have been in textiles, not clothing. Clothing has experienced a modest growth in employment ( 1 percent) (Table 15). In absolute terms, public and private sector firms share job losses equally. However, because employment in the private sector is more than 11 -fold its public counterpart (see Table 15), the rate of job loss has been much higher in public firms, where 1 in every 5 workers have lost their job ( -19 percent). In terms of market orientation, nonexporters (firms only serving the domestic TC market) are hit extremely hard, with three quarters of all job losses originating from these types of firms.

Qualifying Industrial Zone (QIZ) firms, which are responsible for more than half of total sample employment, have actually created jobs (335) between the two years, despite the crisis (Table 16). But this rise in employment is puzzling in light of the sharp declines in QIZ firms' production by one third (Table 9). Similarly, clothing firms have created a few jobs but experienced a decline in production of a quarter. These seemingly paradoxical findings are driven by one QIZ clothing firm ${ }^{23}$, which increased employment by $1200^{24}$ between 2008 and $2009^{25}$. 
TABLE 15: Sample job losses by activity, market orientation, and sector (2007-2009).

\begin{tabular}{|c|c|c|c|c|c|c|c|}
\hline & Clothing* & Textile & Public & Private & Exporters & Nonexporters & Total \\
\hline Job losses & -295 & 1,961 & 849 & 817 & 425 & 1,241 & 1,666 \\
\hline Share in job losses & $-5 \%$ & $105 \%$ & $51 \%$ & $49 \%$ & $26 \%$ & $74 \%$ & $100 \%$ \\
\hline \% Change in employment 2007-2009 & $1 \%$ & $-9 \%$ & $-19 \%$ & $-1.7 \%$ & $-1 \%$ & $-9 \%$ & $-3.2 \%$ \\
\hline Total sample employment in 2007 & 30541 & 22282 & 4440 & 48383 & 38994 & 13829 & 52823 \\
\hline Share in total employment in 2007 & $58 \%$ & $42 \%$ & $8 \%$ & $92 \%$ & $74 \%$ & $26 \%$ & $100 \%$ \\
\hline
\end{tabular}

Source: Author's calculations based on firm questionnaire [6] using sampling weights. ${ }^{*}$ Negative numbers imply that jobs were created.

TABLE 16: Sample job losses by detailed market orientation (2007-2009).

\begin{tabular}{|c|c|c|c|c|}
\hline & \multicolumn{2}{|c|}{ Exporters } & \multirow[t]{2}{*}{ Nonexporters } & \multirow{2}{*}{ Total } \\
\hline & QIZ & Non-QIZ & & \\
\hline Job losses & $-335^{*}$ & 760 & 1,241 & 1,666 \\
\hline Share in job losses & $-20 \%$ & $46 \%$ & $74 \%$ & $100 \%$ \\
\hline Percentage change in employment 2007-2009 & $1 \%$ & $-6 \%$ & $-9 \%$ & $-3.2 \%$ \\
\hline Total employment in 2007 & 27183 & 11811 & 13829 & 52823 \\
\hline Share in total employment in 2007 & $52 \%$ & $22 \%$ & $26 \%$ & $100 \%$ \\
\hline
\end{tabular}

Source: Author's calculation based on firm questionnaire [6] using sampling weights. ${ }^{*}$ Negative numbers mean that jobs were created.

TABLe 17: Job losses by firm size (2007-2009).

\begin{tabular}{lcccc}
\hline & Small & Medium & Large & Total \\
\hline Job losses (in sample) & 98 & 285 & 1283 & 1,666 \\
Share in job losses & $6 \%$ & $17 \%$ & $-4 \%$ & $-3 \%$ \\
Percentage change in employment 2007-2009 & $-3 \%$ & 6409 & 43249 & $-3.20 \%$ \\
Total employment in 2007 & 3165 & $30 \%$ & $54 \%$ & $100 \%$ \\
Share in total employment in 2007 & $6 \%$ & & $64 \%$ \\
\hline
\end{tabular}

Source: Calculated by author based on IDSC TC firm questionnaire [6] using sampling weights.

Firms solely serving the domestic market are responsible for three quarters of all losses (Tables 15 and 16), compared to their employment share of only a quarter (Tables 14 and 15). Non-QIZ exporting firms are responsible for the rest of the losses (Table 16).

Nonexporters appear to have had excess labor, making it easier for them to purse job losses in response to the crisis. In 2007, non-exporting firms employed 35 workers per real unit of output whilst exporters employed 12 less, that is 23 workers for each unit of output. Thus, despite less relative decline in production for nonexporters (by 5 percent only compared to 24 percent for exporters, Table 9), employment losses have been more than double that of exporters ${ }^{26}$ (Table 16). Hence, during the crisis, nonexporters have restructured to become relatively more efficient: rather than employing $1.5^{27}$ times more workers per unit of real output than exporters in 2007, in 2009 they employed only $1.3^{28}$ times more workers per real unit of output.

With respect to firm size, large firms account for the bulk of job losses (77 percent, Table 17). In fact, medium and large firms are responsible for more than 90 percent of overall job losses. But this is not surprising since small firms employ only 6 percent of overall sample employment. In relative terms, all three sizes are hit more or less in the same way (3 percent for both large and small and 4 percent for mediumsize firms).
4.2.2. Identifying the Effect of the Crisis on Employment. Based on the above, we will assume in the following analysis that all public sector job losses are independent of the crisis, being part of a planned government strategy to liquidate the public sector and lay these workers off ${ }^{29}$. This assumption is supported by the fact that between 2007 and 2008 the public sector has lost 12,995 workers [17].

Real private sector production has declined by 25 percent in the year of the crisis (Table 13). As argued above, part of the decline in production is due to reduced domestic sales driven by increased competition from foreign products, and part is attributable to reduced exports on account of the crisis. Hence, the decline in private sector production on account of the crisis is taken as the total decline of 25 percent less than the precrisis (2004-2008) fall in production of -18 percent, which is assumed would have happened anyway (Table 18). That is, nearly three quarters (73 percent) of the reduction in production growth rate is attributable to the crisis. A similar calculation yields 2.3 percent of the decline in employment being on account of the crisis: that is, 594 jobs.

The remainder of the job losses (220 given in column 7 ) is to be blamed on growing imports gradually replacing domestic production, a trend that had already started before the crisis. We may call that the effect of the sector's liberalization. In summary, the crisis is responsible for a large 
TABLE 18: Overall job loss estimate in the industry attributable to the crisis (2007-2009).

\begin{tabular}{|c|c|c|c|c|c|c|}
\hline \multirow[t]{2}{*}{$(1)$} & (2) & (3) & (4) & (5) & (6) & (7) \\
\hline & $\begin{array}{c}(-11 \%+2 \%- \\
14 \%-4 \%) / 4 \\
\end{array}$ & $(1)-(2)$ & $(-18 \% /-25 \%)$ & & $(4) *(5)$ & $(5)-(6)$ \\
\hline \multicolumn{3}{|c|}{ Real private sector production growth rate } & \multirow{2}{*}{$\begin{array}{l}\text { Percentage of } \\
\text { overall growth } \\
\text { reduction }\end{array}$} & \multicolumn{3}{|c|}{ Private sector job loss estimate } \\
\hline $2008 / 2009$ & $\begin{array}{c}\text { Average } \\
\text { 2004-2008 }\end{array}$ & On account of the crisis & & Overall job losses & $\begin{array}{l}\text { On account of } \\
\text { crisis }\end{array}$ & $\begin{array}{c}\text { Liberalization } \\
\text { effect }\end{array}$ \\
\hline$-25 \%$ & $-7 \%$ & $-18 \%$ & $73 \%$ & 814 & 594 & 220 \\
\hline
\end{tabular}

Source: Author's calculation based on IDSC [6] survey data.

part, precisely three quarters (column 4), of the slowdown of the sector.

4.2.3. Restructuring of the Industry. There has been restructuring in response to the sector's liberalization, the QIZ agreement, and possibly also in response to the crisis. Notably, there is evidence of a modest substitution effect whereby exporters have increased their, already significant, share in the domestic market, rising from 63 to 68 percent from 2004 to 2008, thereby increasing it from 63 to 68 percent (Table 19). Domestic sales of nonexporters have been in continuing decline since 2004, though their market share rose slightly (from 33 to 36 percent) in 2009 as sales from QIZ exporters in particular fell more rapidly. So the 36 percent represents a rising share of a contracting market, the total value of domestic sales falling sharply across the period reflecting increased foreign competition since the liberalization of the sector, especially from China.

This restructuring may be explained by at least two factors. First, exporters are more than 1.5 times more efficient compared to producers serving the largely protected domestic market. According to the sample, average yearly productivity per worker is LE 43,590 per worker for export firms compared to only LE 28,864 for firms serving the domestic market. This higher efficiency allows firms to cut prices in the domestic market in order to capture market share $^{30}$.

Indeed, 61 percent of exporters in the sample cut prices in response to the crisis, with an average price reduction of 18 percent. Given their growing market share, it is likely that exporters were already reducing prices before the crisis. Fifty-five percent of producers for the domestic market ${ }^{31}$ also claim they have cut prices, but the aforementioned difference in efficiency has driven different results for market share.

The second factor is the export subsidy offered by the Export Development Fund, which ranges from 8 to 10 percent of total export value. The TC sector is the main beneficiary of incentives offered by the fund, obtaining around 58 percent of all fund assistance [18]. The subsidy allows export firms to cross subsidize, thus further reinforcing their ability to cut prices and drive firms out of the domestic market. Hence this policy - which is very expensive in terms of the job losses it might prevent in exporting firms ${ }^{32}$ - is having a damaging effect on domestic producers, accelerating job losses amongst those firms ${ }^{33}$.
Yet a stronger restructuring trend has been particularly more pronounced within exporting firms. Producers in nonqualifying industrial zones (non-QIZ) have taken over the domestic market from their QIZ firm counterparts increasing their share by a quarter from 2004 to 2008, and by 13 percent in just one year (the year of the crisis). This trend has started not long after the ratification of the QIZ agreement. For example, in just one year between 2006 and 2007, non-QIZ firms have increased their domestic sales by about a half (46 percent) increasing their share by a third from 20 percent to 30 percent. Their sales increased again during the year of the crisis by 9 percent resulting in another 10 percent increase in market share. As a result, whilst nonQIZ firms capture about half of the domestic market (45) QIZ firms capture currently only a fifth of it (their share has declined from nearly a half (43 percent) in 2004 to 19 percent in 2009).

Enjoying no preferential access to the US market, especially after the expiry of the MFA, and facing reduced worldwide export demand, non-QIZ exporting firms find the still largely protected ${ }^{34}$ domestic market attractive. Since the launch of the QIZ protocol in 2005, there has been a gradual decline in exports to the US from non-QIZ areas (Table 20) reflecting three potential movements: (1) switching of existing non-QIZ exporters to QIZ locations, or, alternatively, lobbying to have their locations included (and accordingly become QIZ firms); (2) new investments being created in QIZ zones, thus an expansion of QIZ firms by additional new firms; (3) exporting firms either downsizing, or switching wholly (i.e., exiting the export market altogether) or in part to the domestic market.

As is evident from the above analysis, non-QIZ firms are indeed increasing their share in the domestic market, that is, the third explanation in the previous paragraph. Also, there is substantial evidence that FDI has risen sharply since 2005, following the QIZ agreement ${ }^{35}$ (a tenfold increase compared to levels of 1996) (Figure 5), thus supporting the second argument above ${ }^{36}$. Indeed, investment in the sector has sharply increased by nearly 300 percent during the 13 years from 1995 to 2007 , from a modest $\$ 89$ million to $\$ 351$ million (Table 21, Figure 5). This growth has been uneven, with growth hikes in 2000 and again in 2005. Thus, it is likely that all three factors suggested above have played a role. The balance between the three alternatives remains a matter for further investigation. 


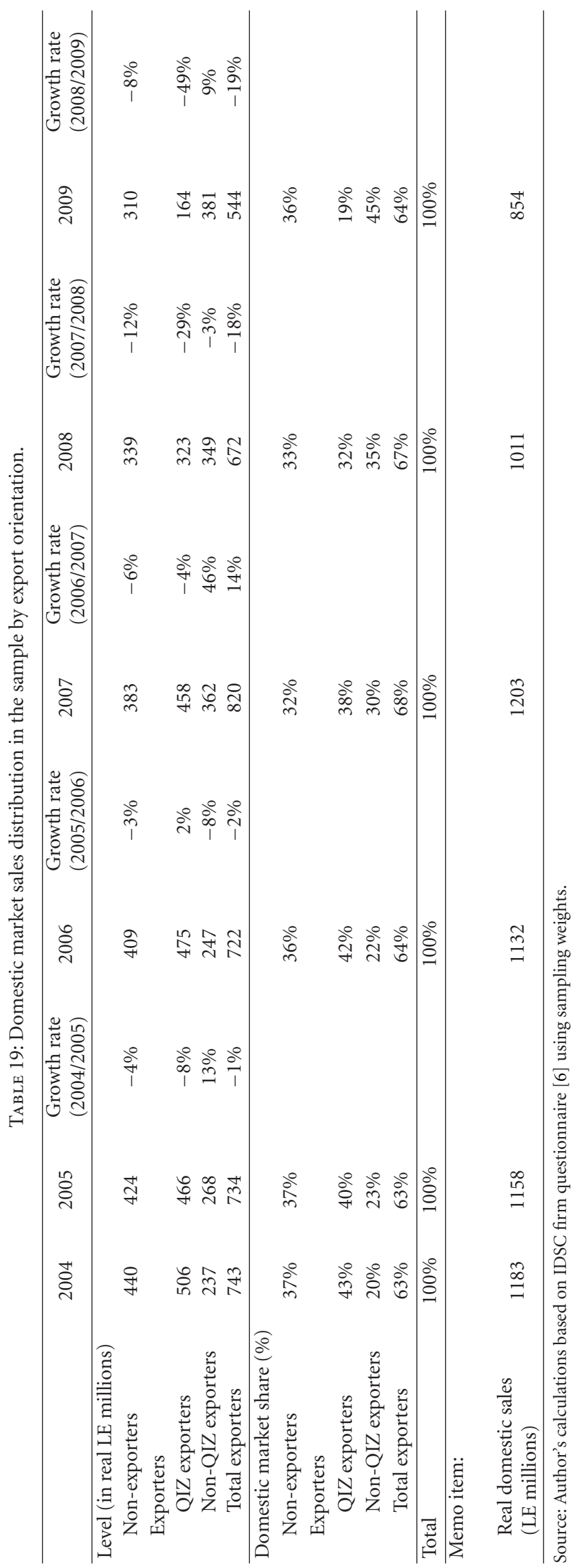


TABLE 20: QIZ/non-QIZ TC and total exports to the US (2005-2009).

\begin{tabular}{|c|c|c|c|c|c|c|c|}
\hline & 2004 & 2005 & 2006 & 2007 & 2008 & 2008 (Jan-Oct) & 2009 (Jan-Oct) \\
\hline \multicolumn{8}{|l|}{ Textiles and clothing } \\
\hline \multicolumn{8}{|l|}{ Level (million US\$) } \\
\hline QIZ TC exports & 0 & 252 & 632 & 730 & 776 & 655 & 662 \\
\hline Non QIZ TC exports to the US & 580 & 375 & 187 & 145 & 139 & 119 & 98 \\
\hline Total TC exports to the US & 580 & 627 & 819 & 875 & 915 & 775 & 759 \\
\hline \multicolumn{8}{|l|}{ Growth rate $(\%)$} \\
\hline QIZ TC exports & & & $151 \%$ & $16 \%$ & $6 \%$ & \multicolumn{2}{|c|}{$1 \%$} \\
\hline Non QIZ TC exports to the US & & $-35 \%$ & $-50 \%$ & $-23 \%$ & $-4 \%$ & \multicolumn{2}{|c|}{$-18 \%$} \\
\hline Total TC exports to the US & & $8 \%$ & $31 \%$ & $7 \%$ & $5 \%$ & \multicolumn{2}{|c|}{$-2 \%$} \\
\hline \multicolumn{8}{|l|}{ All commodities } \\
\hline \multicolumn{8}{|l|}{ Level (million US\$) } \\
\hline Total QIZ exports & 0 & 266 & 644 & 740 & 872 & 733 & 706 \\
\hline Total non QIZ exports to the US & 1330 & 1825 & 1750 & 1640 & 1498 & 1234 & 1023 \\
\hline Total Egyptian exports to the US & 1330 & 2091 & 2393 & 2380 & 2371 & 1967 & 1729 \\
\hline \multicolumn{8}{|l|}{ Growth rate $(\%)$} \\
\hline Total QIZ exports & & & $142 \%$ & $15 \%$ & $18 \%$ & \multicolumn{2}{|c|}{$-4 \%$} \\
\hline Total non QIZ exports to the US & & $37 \%$ & $-4 \%$ & $-6 \%$ & $-9 \%$ & \multicolumn{2}{|c|}{$-17 \%$} \\
\hline Total Egyptian exports to the US & & $57 \%$ & $14 \%$ & $-1 \%$ & $-0.4 \%$ & \multicolumn{2}{|c|}{$-12 \%$} \\
\hline
\end{tabular}

Source: USITC [20].

TABLE 21: Investment in TC by nationality $(1995,2007)$ in US\$ millions.

\begin{tabular}{lccc}
\hline & 1995 & 2007 & \% change between 1995 \& 2007 \\
\hline Domestic & 76 & 227 & $199 \%$ \\
Arab & $85 \%$ & $65 \%$ & \\
& 2 & 49 & $2350 \%$ \\
Foreign & $2 \%$ & $14 \%$ & $582 \%$ \\
\multirow{2}{*}{ Total investment } & 11 & 75 & \\
& $13 \%$ & $21 \%$ & $294 \%$ \\
\hline
\end{tabular}

Source: GAFI [22]. * Issued capital used as proxy for investment. ${ }^{*}$ Data are converted from LE to US\$ using the official exchange rate published. ${ }^{*}$ Data cover companies operating under law 8/1997 both inland and free zones, and companies organized by the companies law 159/1981.

In summary, there is restructuring whereby producers unprotected by the QIZ agreement are turning to the largely protected domestic market. Moreover, about three quarters of the decline in private production and employment is attributable to the crisis. Contraction in domestic sales is largely independent of the crisis, whilst those in exports are directly set off by it. The remainder of the decline, however, is a more structural and gradual trend triggered by the changing global environment on the one hand and the sector's own long inherent structural problems on the other. In real terms, the sector is in decline. The crisis has only exacerbated the contraction of an already struggling industry.

4.3. Social Dialogue: Is There Any? Fourteen percent of firms' managers and CEOs responded that there had been

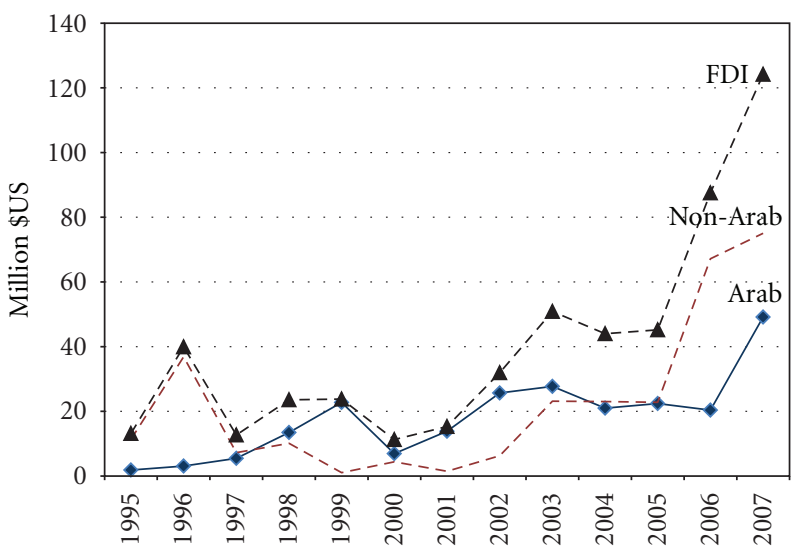

Figure 5: Evolution of FDI in TC Classified into Arab and NonArab (1995-2007). Source: GAFI [22]. * Issued capital used as proxy for investment. ${ }^{*}$ Data are converted from LE to \$US using the official exchange rate published.

substantial job losses when directly asked if they had laid off workers in response to the crisis $^{37}$. But the employment data in the survey suggest that a much higher percentage of firms_-just under half (47 percent) —incurred job losses. Moreover, the number of reported job losses is only half the number of overall losses based on the answers collected directly from the books of the firm ${ }^{38}$. Approximately 40 percent of firms did not inform the worker before the layoff. The rest (60 percent, i.e., 24 firms) report they gave at least a week's notice ${ }^{39}$. A majority (97 percent) claim to have given the worker all his/her financial entitlements after layoff. Surprisingly, only 7 percent of workers ( 285 workers) believe firms have actually laid off workers in response to the crisis. 
TABLE 22: Employment procedures other than layoffs undertaken in response to the crisis.

\begin{tabular}{lc}
\hline Procedures undertaken in response to the crisis & \% of firms \\
\hline Cancel extra work in firm & 44 \\
Stop new hiring & 23 \\
Reduction in daily working hours & 9 \\
Laying off temporary workers & 5 \\
Cancellation of extra pay and allowances & 3 \\
Productivity enhancing procedures & 3 \\
Wage reductions & 2 \\
Cancellation of monthly incentives & 2 \\
Reduction of social and other benefits & 2 \\
Granting open leave to permanent workers & 1 \\
Increase in unpaid additional work hours & 0 \\
Transfer of workers to other branches & 0 \\
Transfer of workers to other firms & 0 \\
\hline
\end{tabular}

Source: Calculated by author based on IDSC firm questionnaire [6].

Virtually none of the firms reported consulting workers' representatives/unions in relation to any measures undertaken in response to the crisis (Table 22), and there was only one case of collective bargaining between firms and the affected workers. Collective bargaining takes place in cases of substantial layoffs or drastic employment measures in any one firm, hence, is likely to be low in the sample since only a quarter (27 percent) of the firms have had job losses of over 50 percent of their work force. On the other hand, 7 percent of the workers have reported some dialogue between them and high level management during the course of the crisis. Only 2 percent of all workers believe workers' or trade unions play an active role in negotiation, suggesting either that there was indeed little consultation, or that the large majority of workers were not involved in any way in such consultations that did take place. Recent developments in labor law have made it easier for firms to lay off workers, making consultation less likely ${ }^{40}$.

\subsection{Other Effects of the Crisis}

4.4.1. Firms' Perspectives. Limited access to finance is perceived as the main effect of the crisis, followed by increases in production costs (according to 77 percent of respondents), then piling up of inventories (57 percent due to unsold production). Eighty-five of the firms have indicated that production costs have risen since September 2008 and an outstanding majority of those (92 percent) blame it on increases in costs of intermediate and raw materials.

Only 8 percent of workers have reported ever receiving training on the job. Seventeen percent of firms have already reduced investments in machinery and 8 percent have reduced the already modest amount of training, but three quarters of firms have reduced capacity utilization (Table 23).

In line with the reduction in production, sales, and exports since September 2009, about 500 existing contracts
TABLE 23: Reductions in expenditures in response to the crisis.

\begin{tabular}{lcc}
\hline & Frequency & \% of Firms \\
\hline Reduced capacity utilization & 203 & 74 \\
\hline Cut expenditures & & \\
On machinery and equipment & 47 & 17 \\
On buildings & 37 & 13 \\
On training & 22 & 8 \\
On R\&D & 17 & 6 \\
\hline
\end{tabular}

Source: Author's calculation by author based on IDSC firm questionnaire [6].

have been cancelled in the sample with an overall value of LE 70 million (current prices). Most of the cancelled contracts (66 percent of them) were for garments. Some buyers have also been late in payments (reported by 14 firms) others have been particularly stringent when it comes to quality specifications (6 firms). On the suppliers' side, suppliers have been demanding higher prices ( 17 percent of all sample firms), have reduced grace periods (15 percent), or have reduced contracted amounts (11 percent). Firms believe the government should give financial subsidies (66 percent of firms) and reduce the number of taxes levied (62 percent of firms) to ease the effect of the crisis on firms in the sector.

4.4.2. Workers' Perspective. Not all surveyed workers had heard of the crisis (only 70 percent of the 5383 workers had done so). Forty-two percent of those (1600 workers or 30 percent of sampled workers) believe the crisis affected them. Income-related effects top the list (Table 24) followed by nonincome effects (e.g., working hours, fringe benefits...etc.).

4.4.3. General Worker-Related Problems. The scarcity of trained and educated workers remains the top problem faced by firms in the industry (77 percent of firms). High resignation rates or turnover rates also represent a problem expressed by 40 percent of sample firms. More than half the firms of the sample thought that the youth have no desire to work in the sector mainly due to their belief that workers prefer desk work (as reported by 70 percent of firms), followed by low wages and salaries in the sector $(60$ percent of firms), and difficult work conditions such as large distance between work and home (31 percent).

On the other hand, based on the workers' questionnaire, only a fifth of them state that they have problems related to their job in the TC sector. Not surprisingly, modest salaries and wages top their list of reasons (65 percent of those stating to have problems) followed by fear of financial crisis repercussions ( 23 percent), and worker layoffs (18 percent of them).

\section{Conclusion and Policy Recommendations}

The downturn in the sector between 2008 and 2009 is largely driven by the crisis. But the sector had already been in decline on account of changes in the global environment ${ }^{41}$. 
TABLE 24: Workers' perception of firms' reductions in expenditures due to the crisis.

\begin{tabular}{lcc}
\hline & No. workers & \\
\hline Reduction in & 1070 & 67 \\
Income & 1043 & 65 \\
Bonuses & 823 & 51 \\
Periodic salary raises & 614 & 38 \\
Working hours & 611 & 38 \\
Services firm provides to employees & 601 & 38 \\
Paid holidays & 545 \\
Fringe benefits (e.g., meals, transport) & 463 \\
Giving unpaid leave & & 34 \\
Memo item: & 1600 \\
Total number of workers stating they are affected by crisis & 29 \\
\hline
\end{tabular}

Source: Calculated by author based on IDSC worker questionnaire [6].

So while sharp reductions in exports are mainly triggered by the crisis, reductions in firms' domestic market sales have been accelerated by the sector's liberalization and corresponding increased foreign competition in the domestic market. Reductions in employment have followed the decline of exports, domestic sales, and consequently of production. Some restructuring is evident: exporters unprotected by preferential trade agreements are turning away from the export market to the still largely protected domestic market. It has become evident that the sector as it stands now cannot withstand fierce international competition. How is policy going to respond to these consequences in addition to the more structural and inherent problems of the industry?

Policy has to tread a fine line between insulating the economy from the temporary effects of the crisis and avoiding overdistorting incentives. Exporting firms now moving into the domestic market are unlikely to abandon it even if export prospects pick up. So government measures are needed but should be tailored so as to avoid "excessively paying for inefficiency." But provided some restructuring is efficient (since only the least efficient firms exit the market), policy should avoid "accelerated restructuring" due to massive job losses that are not outweighed by comparable job creation. Hence, we encounter a policy dilemma. What is to be done?

\subsection{Short- and Medium-Term Policy Recommendations}

5.1.1. Labor Market Policies. There has been a 3.2 percent decline in employment in the sample. Increased public expenditure on infrastructure may help in the short run. However, in the medium term efforts should be focused on improving labor mobility ${ }^{42}$ toward more productive sectors. If unemployment is inevitable then an efficiently and transparently run unemployment benefit system ought to be in place. Workers' representatives have called for the establishment of a publicly financed fund to combat unemployment [31]. However, such a fund is not being considered by the Government ${ }^{43}$, for which there is good reason. Especially for private sector firms there is a problem of asymmetric information so that it is very costly, if not impossible, for the government to identify who is genuinely jobless. However, unemployment benefits for six months are part of a recent discussion of the insurance and retirement draft law. Since the study has shown that job losses have been mostly concentrated in the most vulnerable groups of workers (i.e., illiterates and those with primary education) as confirmed by firms in the industry, the passing of this law is of paramount importance to help soften the effect of the crisis on poverty.

The government may also undertake more direct interventions such as paying for the social insurance $[32,33]$ of the workers in badly hit firms in order to prevent them from laying off workers. As a temporary solution firms ought to resort to reducing wages and/or their working hours rather than laying off labor altogether $[33,34]^{44}$. Additionally, firms should utilize idle time to train those workers. The government may also advertise for largely subsidized retraining programs for the currently but temporarily unemployed, thus utilizing the slowdown positively.

5.1.2. Fiscal and Monetary Policy Measures. To counter the sharp contraction of manufacturing industries caused by the crisis, the government's main focus has been directed towards boosting aggregate demand but should also be directed towards ensuring that credit is available to businesses that may only be temporarily liquidity constrained. The government of Egypt is aware of this need, having implemented two stimulus packages to date, with a third underway.

The packages rest on four pillars: (1) increasing public expenditure, mainly on infrastructure, (2) a two-stage reduction in interest rates, (3) providing various incentives to the private sector to stimulate investment and improve the business climate, and (4) increasing current expenditure of which a substantial part (LE 2.1 billion LE, i.e., 80 percent) goes to increase export competitiveness, an expense that is to be distributed by the Export Development Fund.

Egypt has a tight fiscal policy space, hence fear of mounting public debt and resulting inflationary pressures on the economy is at the center of a debate around the packages. 
In addition, the adequacy of the packages to compensate for the negative effects of the crisis is questionable. Nevertheless, the current temporary cut in customs duties and sales taxes on industrial inputs and capital goods may ease the pressure somewhat, and has a faster impact than does government expenditure, such as that on infrastructure, actual disbursements of which may be delayed for practical, administrative, and logistical reasons. Removing or substantially reducing sales taxes (for a preannounced limited period) may also boost domestic demand along with increases in infrastructure. Infrastructure programs should be targeted to alleviate supply bottlenecks, which can include public housing near industrial zones.

5.1.3. Trade Policy Measures. Efforts to increase the geographical diversity of Egypt's TC trading partners need to be strengthened by increased competitiveness, resolving implementation problems under the Greater Arab Free Trade Area (GAFTA) and negotiating free trade agreements with new partners. Reviving stalled trade talks with the USA to first relax conditions on TC exporters currently applicable under the QIZ agreement, and second to lobby for better market access for non-QIZ exports, as many of these exports do not benefit from the US Generalized System of Preference (GSP) treatment under US trade rules ${ }^{45}$. Egypt's exporters are not making sufficient use of the US GSP system: an estimated 10 percent of exports to the US that would benefit from GSP are subject to regular MFN tariffs on account of incorrect labelling [35] ${ }^{46}$.

There should not be recourse to increased protectionism, but further reductions in tariffs should be implemented gradually. Since the phase-out of the quota system in 2005, Egypt has imposed a number of remedy actions though dealing with the genuine structural problems underlying the industry remains the most sensible policy route. Protectionist measures such as tariffs create a bias against exports by increasing the price of foreign competing products on the domestic market rendering the domestic market relatively more attractive for domestic producers and increases domestic market prices borne by domestic consumers.

Providing conditional and finite incentives ${ }^{47}$ for exporters has generally been a successful way to build up strong industries and penetrate export markets (e.g., South Korea), yet "excessive" protection backfires. As seen earlier, restructuring has been evident whereby firms solely catering to the domestic market are driven out of that market. It is true that these are the least efficient firms but the enlarged export subsidy artificially increases the competitiveness of exporting firms, hence possibly leading to restructuring not purely based on efficiency. More importantly, it has led to substantial job losses amongst domestically oriented producers. These job losses are based on the sample, which includes firms that still exist in the market; therefore, accounting for additional job losses originating from firms exiting the market altogether would lead to larger estimates, and so make an even stronger argument. The job losses effect is not solely caused by the crisis but also by the further effect competition from foreign imports is placing on firms producing for the domestic market. The increase in the export subsidy rate provided by the fund has not been renewed in the second stimulus package and should also not be renewed in the third stimulus package for the reasons just given. Nevertheless, the export subsidy should not be cancelled altogether ${ }^{48}$.

\subsection{Longer-Term Policy Recommendations}

5.2.1. Realities of the Sector. As a cotton producer with a substantial domestic market for final products, one might expect to see a large, competitive industry serving that market. And given that Egyptian cotton is amongst the world's best, a vibrant high-end export sector might also be expected. Unfortunately, neither of these is the case.

Egypt benefitted from the Multi-Fiber Arrangement (MFA). The country's exports were not close to its quota limits, gaining from the fact that more competitive countries like China, Bangladesh, Vietnam, and even Turkey were constrained. With the tariff reductions required by Egypt's membership to the World Trade Organization (WTO), Egyptian producers are unable to compete with lower cost overseas producers, especially those in China, losing market share at home, and would have done so abroad were it not for continued preferential treatment, notably under the European-Mediterranean Partnership agreement entering into force in 2004 and the Qualified Industrial Zones (QIZ) arrangement with the USA and Israel, which came into force in 2005-nearly three-quarters of TC exports fall under these agreements. In spite of the fact that Egypt also benefitted from both the USA and EU applying safeguard quotas on China since 2006 (on 34 categories in the case of the US and 10 in the EU case since 2006) ${ }^{49}, 50$. The Ministry of Trade and Industry is taking determined and successful steps to enlarge the scope of the QIZ ${ }^{51}$. But Preferential Trade Agreements are politically tenuous and cannot be counted on to build the sector in the long term.

\subsubsection{Long-Term Strategy for the Development of the Industry.} There are four pillars of a strategy for the sector in order to capture further value added at home.

Pillar 1: Moving Up the Clothing Industry Value Chain. Move up the clothing value chain through targeting high end export markets characterized by higher value added export items, such as high end clothing, but with a focus on products for which Egypt has some specialized experience (e.g., carpets), and in simple products, such as linen, where the proximity to the raw material provides a cost advantage. The possibility can be explored of high-value exports using Egypt's long-staple (LS) and extra long-staple (ELS) cotton but also through the use of new materials such as microfibers ${ }^{52}$.

It is true that world demand on Egyptian LS and ELS cotton has declined because of the advent of new materials (e.g., manmade fibers) ${ }^{53}$ and the rise of the American Pima cotton, which is supported by the American subsidy program $^{54}$. Nevertheless, Egypt does export about 15 percent of its total TC exports in the form of unprocessed cotton, which it can alternatively process locally so as to capture 
the value added domestically. In the final market the difference is substantial; a woven Japanese produced shirt is sold for $\$ 120$ while its Egyptian yarn content amounts to just $\$ 5$. Moving up the value chain would increase value added retained at home.

To reverse the situation so cotton is used at home, immense investments are required. Either the private sector undertakes these investments after the purchase of privatized spinning and weaving facilities or the government undertakes these investments prior to privatization. Each of these options, however, entails potential risks. For the former, the private sector has been engaging in the so-called "land cooling," that is, leave their newly purchased facilities for some time-usually years-and later make a large capital gain on the sale of the land. Indeed, the current value of the spinning and weaving companies resides mainly in their real estate value given their poor technological status $[11]^{55}$. Eventually the original activity of these factories is not repursued, which leads to a disinvestment in this vital sector of the economy. This fact may favor the second option, though the problem with the government undertaking these investments is that the government may not make the most desirable or optimal business decisions, so a PPP (Private Public Partnership) may be desirable. Or alternatively devise enforceable contracts ensuring that the firm will remain in the textile business in return for a low sale price, for instance. Under these conditions, privatization can boost competition of firms in the various sectors of the upstream industry (mainly spinning and weaving) so that Egyptian firms can turn their high quality cotton fibers into equally high quality yarns and fabrics.

Other incentives should also be considered. Countries such as India support spinning producers who use cotton in their production through a number of methods including concessional interest rates, with government bearing the difference between the commercial and concessional rate. It also contributes to nearly 20 percent of the infrastructure of these firms [17]. Egypt could also consider similar policies to encourage the use of Egypt's high value cotton provided it is used to spin fine yarns.

Pillar 2: Provision of "Genuinely" Conditional Export Incentives with Extra Support to Industrial Deepening. The second pillar is the provision of "genuinely" conditional incentives. Conditionality remains necessary on many fronts. As the government increases export subsidies to deal with the financial crisis, it is vital to ensure higher levels of transparency and accountability in order to guarantee that those receiving the subsidies are those who are entitled to them without favoritism or nepotism. Tying performance to incentives is key to successful incentive structures. The subsidy should also be given on the value added portion and not on the final value of exports. Furthermore, support should be provided to those firms that are investing in fine cotton spinning technology, those that are placing themselves into competition with Japan and Italy similar to the path taken by Indian, South Korean, and Pakistani firms, to whom the country is now losing market share. These countries have become major importers of Egypt's superior quality cotton.
In other words, extra support should be targeted to those exporters entering high end market niches, utilizing Egypt's high quality cotton fibers to produce high quality yarns, fabrics, and clothing.

Pillar 3: Training, Capacity-Building, and Skills Upgrading. Increasing productivity remains a key challenge for the coming years. An essential requirement to raising productivity includes improving the quality of education at all levels, adopting a clear and well-targeted training strategy, establishing a closer link between performance and pay, and last but not least enhancing and repairing the poor work environment and ethical standards.

A recent study about the clothing sector concluded that by addressing its productivity problems Egypt could increase its clothing exports by 25 to 40 percent [36] ${ }^{56}$. Endeavours to increase productivity may also be strengthened by Egyptian firms undertaking joint ventures with foreign firms including Vietnamese and South Korean for know-how and skill (marketing, networking, and quality standards) acquisition. Public private partnerships in the spinning and weaving but also in the printing and dyeing sectors may be a reasonable option because of the large investment cost involved. Moreover, as opposed to creating new institutions and/or expanding existing ones for training (e.g., the Industrial Modernization Centre, the Textiles Technology Center, and other capacity building programs such as the ones provided by the National Research Center), cost reductions will be effected through the private sector taking initiative in training employees, with the government's role restricted to providing "conditional" cash transfers to such firms ${ }^{57}$.

Pillar 4: Undergo a Comprehensive Institutional Reform. Productivity can be enhanced by government investments in both infrastructure and improved governance. The government of Egypt announced that it will establish two industrial zones in Borg Al Arab and Sixth of October cities for textile production to become the biggest in the industry in the Middle East region. But, for competitiveness it is the institutions that matter, not just the physical infrastructure. Business in Egypt suffers from a bureaucracy that is both excessive and inefficient. It is excessive in that the degree and time required for business registration and other reporting requirements are beyond those necessary for a market economy and so constrain the growth of that economy. It is inefficient since government has been slow to adopt modern technologies, such as IT-based systems, or to reform the bureaucracy itself. A comprehensive institutional reform for all public institutions including government bureaucracy is warranted. Government employees need a change in their mindset if they are to contribute to Egypt's growth, rather than hinder it. The old ways, including carelessness, petty corruption, and control for control's sake, are deeply ingrained in the system. Improved incentives, both rewards and penalties, coupled with strict monitoring will help bring about this changed mindset, but more concerted and direct efforts may be needed given the depth of the problem. 
TABLe 25: Employment in TC data discrepancies (2006).

\begin{tabular}{lcc}
\hline \multicolumn{2}{c}{$\begin{array}{c}\text { Central agency for public mobilization and statistics (CAPMAS) } \\
\text { Annual industrial statistics }\end{array}$} & Industrial development authority \\
\hline 278267 & 335477 & IDA \\
$0 \%$ & $21 \% \uparrow$ & 400384 \\
\hline
\end{tabular}

\section{Appendices}

\section{A. A Note on National Sources' Data Discrepancies}

There are numerous examples for data discrepancies in TC databases in Egypt. Employment is most palpable, for which there appears to be a discrepancy within the Central Agency for Public Mobilization and Statistics (CAPMAS's) different data sources (Table 25) reaching as much as 22 percent. Data from the Industrial Development Authority indicate that total employment in the TC sector equals 400,384; 44 percent higher than that reported by CAPMAS.

CAPMAS is the only source that provides comprehensive data on every aspects of the economy, hence its appeal. CAPMAS has extensively reformed itself in terms of digitization of data and more openness on data disclosure and certainly also on the quality of data. Nevertheless, successful reforms may take years to be completed. It is necessary to launch a National Plan for Data Availability, Accuracy, and Unification, whereby each and every company obtains one and only one identification number (ID), for example, the number given at registration with the commercial registrar, similar to the national identification card system for citizens that the government of Egypt has successfully implemented. Data collection should be confined to the particular institution most relevant and closest or direct to the information (e.g., import data should be confined to the customs authority and export data to the General Organization for Export and Import Control (GOEIC) and should be automatically entered at the port of entry rather than later collected through a survey instrument as in the case of CAPMAS).

Every particular authority should report directly and digitally to CAPMAS and should share with it the responsibility of double-checking the data before they are made public. Search by firm ID can then be made available on all relevant data. Identities of companies remain confidential with each of the collecting authorities, but can of course be centrally traced. Issues of differing classifications of the various indicators amongst the different institutions should be resolved by following international best practice: the Harmonized System (HS) for trade data and the National Accounts' International Standard Industrial Classification (ISIC) for production data. For any departure, concordance tables that match the systems to each other should be available and easy to obtain.

No accurate evaluations can be performed when the underlying data are inaccurate, and in turn no accurate policy recommendations can be drawn. The government of Egypt is indeed aware of data problems. As a step in that direction, CAPMAS has signed a deal with the GOEIC whereby they receive their data from GOEIC. A comprehensive information and data reform requires similar deals with all relevant institutions. It is essential that the management for all these institutions deeply believe in the importance of accurate and transparent information and at the same time possess the caliber to enforce data quality standards and issues of transparency.

\section{B. Labor Movements and the Labor Law}

Worker unrest has been growing. There were 137 protests in the TC sector in 2007 alone, compared to a total of 107 for the seven years from 1998 to 2004. Moreover, these strikes were not confined to public sector companies as had been the case in the 1980s and 90s. Strikes are based on demands for higher wages, benefits, and better working conditions on the one hand to more general political concerns (e.g., the relation between workers and the General Federation of Egyptian Trade Unions and the government). Public sector strikes have focused on protecting workers' pay and conditions, including enforcing collective bargaining deals related to early retirement. But there have also been strikes against privatization altogether, such as that in the Qalyub Spinning Company, which was previously a branch of ESCO. Workers also demanded an independent trade union federation, which was behind protests in the Misr Spinning and Weaving facility in Mahalla al-Kubra (December 2006), the Shebin al-Kom Spinning and Weaving Company (February 2007), and Kafr al-Dawwar. Private sector strikes were against poor and worsening work conditions, layoffs, company or factory closures, increases in working hours, or reduction of wages, and to demand payment of delayed salaries, higher wages, or work injury compensation, and to object to penalties, mistreatment of workers, and low quality services [37-39].

Many of those recent protests have been effective. For example, workers' strikes, along with opposition efforts in the parliament, successfully prevented the privatization of Delta Spinning and Weaving Company (2005) [39]. The increase in unrest in part reflects the reactions of labor to the implementation of the greater flexibility around employment practices afforded by the unified Labor Law of 2003. The new law gives employers more flexibility, in relation to the termination of contracts for reasons of force majeure or negative economic circumstances (such as the current crisis) and working hours, as well as allowing fixedduration contracts and employment on probation for up to three months. Workers are guaranteed compensation of job termination and the right to strike peacefully in defense of their professional, economic, or social interests ${ }^{58}$.

Although the new Labor Law has facilitated the firing process, firing costs remain high, at an average of 132 weeks 
TABLE 26: The cost of one job saved, job losses, exports, and subsidies.

\begin{tabular}{|c|c|c|c|c|c|c|}
\hline & $\begin{array}{l}\text { Total job losses } \\
\text { for exporters } \\
\text { between } \\
2008-2009\end{array}$ & $\begin{array}{l}\text { Total exports in } \\
\text { million nominal } \\
\text { LE } 2009\end{array}$ & $\begin{array}{l}\text { Average subsidy } \\
\text { rate }\end{array}$ & $\begin{array}{l}\text { Total subsidy in } \\
\text { million nominal } \\
\text { LE }\end{array}$ & $\begin{array}{c}\text { Cost of one job } \\
\text { saved (million LE } \\
\text { per job) }\end{array}$ & $\begin{array}{c}\text { Cost of one job } \\
\text { saved (LE per } \\
\text { job) }\end{array}$ \\
\hline Regular subsidy rate & 425 & 1218 & $9 \%$ & 110 & 0.258 & 257,694 \\
\hline Crisis subsidy rate & 425 & 1218 & $12 \%$ & 146 & 0.346 & 343,592 \\
\hline
\end{tabular}

Source: Author's calculation based on IDSC firm questionnaire data.

of wages. Excessive social provisions may backfire by discouraging employers from hiring full-time workers formally [40]. Whilst employers have taken advantage of the new law to reduce the labor force, there are allegations they do not honor their compensation obligations, which is a factor behind the recent spate of strikes [23].

\section{Acknowledgments}

Thanks are due to Howard White for a discussion of the content and Angie Mounir for excellent research assistance. The author acknowledges inputs and ideas from Arne Klau. She is grateful to the Information and Decision Support Center (IDSC), especially Maged Osman, Hussein Abdel-Aziz, Zakaria Abdel-Wahed, Mohamed Ramadan, Azza Ibrahim, and Ahmed Heiba for their cooperation and professionalism in conducting the survey. Thanks are also due to Hanaa Kheir-El-Din, Naglaa El Ehwany, Mohamed Kassem, Magdy Tolba and attendees of a roundtable discussion held at the Egyptian Center for Economic Studies (ECES) for comments and suggestions. She is also thankful to Yousef Qaryouti and Amal Mowafy of the International Labour Office/SubRegional Office for North Africa in Egypt. Any errors and omissions are the author's responsibility. The usual disclaimer applies.

\section{Endnotes}

1. The survey was conducted by the Cabinet Information and Decision Support Center (IDSC).

2. In the form of price ceilings under, for instance, the "clothes provision for the people program" or what was termed in Arabic "Al Kesaa El-Shaaby" program.

3. That is, the peasant is subsidizing the factory and the factory is subsidizing the consumer (exact words of Mohamed Kassem, comment during ECES Roundtable, ECES Cairo, February 11th, 2010), a system with absolutely no regard for economic efficiency.

4. This happened via two channels. First, it artificially made the domestic market more profitable, creating an antiexport bias. Second, through limiting consumers" access to foreign products, the demand generated from the largely protected domestic clothing market was limited in terms of quality. With the exception of a minor high-end and a slightly larger middle-market, mass domestic demand came from the low (value) end of the clothing market. Accordingly, with fabric imports being largely constrained by high tariffs and cumbersome import procedures (e.g., duty drawback system and import temporary admission system, especially for those wishing to export clothes) high quality cottonsunable to be exported-were wasted on the production of low quality fabrics and clothing.

5. As it has been precisely summarized: “... the continuous production and distribution of subsidized cotton fabrics at such volume and subsidy, for almost 20 years, dealt a ruining blow to the commercial and development capabilities of the Egyptian textile industry," [the quality of production suffered] ... carelessly produced coarse yarns, spun from high-quality Egyptian cotton lint, were delivered to weavers, who in turn produced poorly woven fabrics to be carelessly bleached or printed and delivered to undemanding customers." (Ministry of Agriculture and Land Reclamation and APRP in American Chamber of Commerce in Egypt 2001).

6. This is because these countries have positioned themselves to become giant textile and clothing manufacturing countries, not only in low-priced textile goods but also in all kinds of textiles. Their increased imports of Egyptian cotton reflects their investments in fine cotton spinning ability, which challenges the European fine cotton spinners for market share.

7. The number of companies under the Holding Company has fallen from 39 in 2002 to 33 by 2009 ([41, 42]).

8. Nine of which are Cotton Ginning, Pressing and Trading Companies, 23 are spinning and weaving companies and one produces spinning equipment. Two of these 33 companies have stopped production and 13 are in deep financial need [42].

9. Since the start of the privatization program until 2006 there had been 5 companies subjected to Majority Public offering, 3 were sold to anchor investor, 1 company was liquidated and 4 under majority sales to employee shareholding associations (ESA) and 5 under leasing [43].

10. For example, it imposed specific tariffs as high as $\$ 300$ per item on more than 1000 categories of clothing when the import ban on clothing was lifted, and when the ban on textiles was eliminated, tariffs of up to 54 percent were imposed (on yarns and fabrics of cotton and manmade fibres (chapters 51, 52, 54, 58, and 60)) ([24] in [12]). 
11. Many of these producers have closed down to become importers from China (Magdy Tolba, comment during ECES Roundtable, ECES Cairo, February 11th, 2010).

12. An example is the case of Salmone El Omash village, $5 \mathrm{~km}$ outside Mansoura. Most inhabitants of this village have been working in the TC industry for more than 40 years. Factories now only operate a third of the year, their profits having been cut by half. They blame this situation on Chinese imports with prices far lower than their products' [44].

13. Overall reduction in production could partly also be attributed to further devaluation of the pound against the dollar between 2000 and 2004 by 78 percent from LE 3.48 to LE 6.21.

14. For more information on the European Mediterranean Partnership agreement cf. El-Haddad [45]; Ministry of Trade and Industry [46]; Kheir-El-Din and Ghoneim [47], and on the QIZ agreement cf. El-Haddad [45]; Ministry of Trade and Industry [48]; Institute of National Planning [49].

15. Cotton lint, yarn and fabric exports lost a share of 1 percent in both US and EU markets, and carpets gained 2 percent in the EU but lost 1 percent in the US market. Note that cotton lint represents more than half of all cotton exports. See El-Haddad [18] for a more detailed assessment of the effect of the end of the MFA on Egyptian export shares in the EU and the US markets.

16. To figure out whether the clothing export sector is selfsufficient, a calculation of imported inputs versus exports would be warranted.

17. The new law gives employers more flexibility, in relation to the termination of contracts for reasons of force majeure or negative economic circumstances (such as the current crisis) and working hours, as well as allowing fixed-duration contracts and employment on probation for up to three months. Workers are guaranteed compensation of job termination and the right to strike peacefully in defense of their professional, economic or social interests. Nevertheless, most recent strikes are illegal. Under the labor law workers must acquire permission from the general federation to protest, which is controlled by the government [37-39].

18. For example, the General Authority for Investment (GAFI) becoming a one-stop-shop for investors in 2004.

19. Which means that firms in the informal sector are excluded.

20. Please refer to Appendix A for a note on data discrepancy problems in more detail.

21. Which are only half the value of clothing exports.

22. That is without a formal contract.

23. An outlier.

24. 689 if sampling weights are used.

25. Without this firm, QIZ (clothing) firm job losses would be 354 (394) using sampling weights and 503 (995) without weights, that is, a negative growth rate of their employment by 2 percent ( 3 percent).

26. Precisely 2.9 calculated as $1241 /(760-335)$.

27. $(35 / 23)$.

28. $(39 / 30)$.

29. That is, until public sector firms either stop production altogether or are privatized, in which case workers of these companies will be considered private sector ones.

30. A similar trend is noticeable in the tourism sector whereby travel agents, airlines, and hotels have reduced their local prices to replace foreign tourists by national ones to compensate for reduced numbers of international tourists [50].

31. Those still remaining as it is likely plenty have exited the market altogether, for which we have no formal count.

32. The cost of one job saved due to this policy roughly amounts to LE 257,694 (calculation performed based on sample data shown in Table 26), which is much larger than the general figure of LE 50,000-150,000 for creating one job in the Egyptian labor market.

33. Note that in December 2008 the Government scaled up all export subsidies (ranging from 8 to 10 percent of total export value) offered by the Export Development Fund by 50 percent for a seven-month period until June 2009. This policy's effect may yet again reinforce exporters' ability to cross subsidize between the domestic and the export market, though the effect may appear with a lag, that is, in data for 2010 .

34. Since MFN rates $\neq 0$ yet.

35. Implying that investments have responded to the QIZ agreement.

36. However, domestic investment still represents the bulk of investments in the industry ( $\$ 227$ million of $\$ 351$ million in 2007) though its share in total investment has been declining in favor of foreign investment (from 85 percent in 1995 to 65 percent in 2007).

37. Question 404 in the firm questionnaire: Did you undertake any of the following procedures in response to the crisis? (1) laying off permanent workers (i.e., those working no less than 8 hours a day 5 days a week) and (2) laying of temporary, seasonal, or part time workers.

38. Questions 307 and 308 asked about overall employment numbers broken down by gender and worker informality status in 2007 and again in 2009. These data were collected from the interviewee but double-checked using the firms' books. The reason why the year 2007 was picked rather than 2008 is to use a complete year with no crisis effects whatsoever.

39. Maximum notice reported by about a third of the 24 firms who claimed to give notice is 4 weeks.

40. Refer to Appendix B for recent developments in labor movements and the labor law. 
41. Inefficient government policies and a lack of a clear strategy for its development rendering the sector uncompetetive were preconditions for this decline.

42. In a recent global ranking that measured labor market efficiency, Egypt ranked 134th out of 134 countries [51]. The indicator "labor market efficiency" is composed of ten subindicators grouped under the two components of labor market flexibility and use of talent.

43. The Minister of Manpower and Migration approved subsidies from the Emergency Fund to 3,134 workers in ten private sector companies that were hit by the crisis. At least two of them are from the textile sector [52]. Nevertheless, institutionalized arrangements, known to all parties, and based on clear criteria, should be put in place rather than ad hoc decisions.

44. Only 9 percent of the firms report they have reduced working hours (Table 23).

45. The Generalized System of Preferences (GSP) is a voluntary, unilateral, nonreciprocal system through which developed countries offer developing countries concessional access to their markets for some products produced by developing countries. Egypt benefits from nonreciprocal preferences under the Generalized System of Preferences (GSP) of Australia, Belarus, Bulgaria, Canada, Japan, New Zealand, Norway, the Russian Federation, Switzerland, and the United States [53, 54]. It is important to note that the Egyptian TC industry has hardly benefitted from this system. While Egypt is eligible to implement the GSP, it is not possible for Egyptian textile and clothing exports to benefit from this system. Implementation of this system requires that commodities must be eligible within the GSP framework. While Egypt is a GSP-eligible country, most of the textile and clothing products manufactured within Egypt are not included within the list of eligible goods [54]. For example, only the following lines are eligible for the US GSP: silk, wool, cotton, carpets, and other floor coverings, special woven fabrics, and textile articles [55].

46. The content of the previous paragraph relies heavily on ideas and suggestions from Arne Klau.

47. Again for a preannounced limited period. Conditionality will be discussed in more detail in the next subsection.

48. In order to provide both export incentives and financial liquidity, so as to counteract crisis borne liquidity constraints.

49. Which terminated in December 2008.

50. That is, TC exports still performed modestly even prior to the crisis.

51. On May, 26th 2009, it was announced that the Ministry of Trade and Industry is signing a plan to incorporate two governorates in Upper Egypt to the qualifying zones.
52. Since technological advances allow producing fine yarns from less expensive cotton lint.

53. Cotton liberalization and continuous price decreases, have also caused successive declines in the cotton crop for over 15 years. The area of planted cotton in 2008/ 2009 has declined by over a half ( 52 percent) campared to the previous season, from 225 thousand metric ton to 108 , its lowest in 150 years [17].

54. The subsidy has reached 30 cents/pound in the 20032004 season [11].

55. What reinforces the matter is that public sector companies are vertically integrated companies which produce through the value chain, thus discouraging private buyers to bid for such huge entities.

56. I am grateful to Arne Klau for drawing this figure to my attention.

57. Rather than charging them a percentage of their sales or profits toward training as is currently the case.

58. Nevertheless, most of the recent strikes are illegal. Under the labor law, workers must acquire permission from the general federation to protest, which is controlled by the government.

\section{References}

[1] MOED (Ministry of State for Economic Development), "Follow-up report for the year 2007/2008," Cairo, Egypt, Ministry of State for Economic Development, 2008.

[2] International Trade Center, "International trade map online database. Geneva: International Trade Centre UNCTAD/WTO (ITC)," 2008, http://www.trademap.org/.

[3] IDA and (Industrial Development Authority), "IDA online database. Cairo: Industrial Development Authority," 2009, http://www.ida.gov.eg/Egmaly_en.html.

[4] IDA (Industrial Development Authority), IDA Unpublished Database, Industrial Development Authority, Cairo, Egypt, 2009.

[5] World Bank, "Morocco, Tunisia, Egypt and Jordan after the end of the Multi-Fiber Agreement: Impacts, challenges and prospects. Washington, D.C.: The World Bank, Social and Economic Development Sector Units," Report 35376, 2006.

[6] IDSC (Information and Decision Support Center), Firm and Worker Questionnaires, Information and Decision Support Center, Cairo, Egypt, 2009.

[7] L. Bulbul and S. Neguib, "2000 Case of urbanization and industrialization in Shubra El-Kheima, Egypt," Urban Partnership Background Series 9, World Bank, Washington, DC, USA.

[8] M. F. Sakr and L. Abdel-Latif, "International competitiveness of Egypt's textile industry," Economic Studies Series \#20, Center for Economic and Financial Research Studies (CEFRS), Faculty of Economics and Political Sciences, Cairo, Egypt, 2000.

[9] Ministry of State for Environmental Affairs and Egyptian Environmental Affairs Agency (UK DFD), SEAM Project, "Textile Sector Report," Tech. Rep., Cleaner Production Opportunities, Cairo, Egypt, 1999.

[10] American Chamber of Commerce in Egypt, "Spinning industry unravels. Cairo, Egypt: American Chamber of Commerce," 
2001, http://www.amcham.org.eg/resources_publications/publications/business_monthly/issue.asp?sec $=17 \&$ subsec $=$ Spinning industry unravels\&im $=11$ \&iy $=2001$.

[11] RATES (Regional Agricultural Trade Expansion Support Program), Cotton-Textile Apparel: Value Chain Report Egypt, Regional Agricultural Trade Expansion Support Center, Nairobi, Kenya, 2005.

[12] A. El-Haddad, "Vertical integration in the Egyptian garment industry: an economic and institutional analysis," Research Papers Series \# 30, . Department of Economics, Faculty of Economics and Political Sciences, Cairo University, Cairo, Egypt, 2008.

[13] A. El-Haddad, "Vertical integration and institutional constraints on firm behavior: the case of the garment industry in Egypt," Economic Research Forum (ERF) Working Paper Series \# 383, Economic Research Forum (ERF), Cairo, Egypt, 2008.

[14] IDSC (Information and Decision Support Center), IDSC Worker Survey Sampling Note, Information and Decision Support Center, Cairo, Egypt, 2009.

[15] World Bank, World Development Indicators [CD-ROM] 2008, The World Bank, Washington, DC, USA, 2008.

[16] IMF (International Monetary Fund), Financial Statistics [CD$R O M]$ 2009, International Monetary Fund, Washington, DC, USA, 2009.

[17] Shura Council, "Preliminary report on the international financial crisis and the Egyptian industry: direct implications to the textile and clothing industry. Egyptian Shura Council," in The Committee on Industrial Production and Energy, 30th Regular Session, 2010.

[18] A. El-Haddad, "Egypt's textile and clothing sector, 19952007," Report Prepared For the Arab Federation for the Textile Industry (AFTI) and the League of Arab States under the Auspices of the Arab Trade and Development Programme, UNDP.

[19] Presidential Decrees 429/2000, 300/2004, and 39/2007, and Laws 8/1997, Law 13/2004 and 91/2005.

[20] "USITC (United States International Trade Commission) USITC online database. Washington, DC, USA, International Trade Commission," 2009, http://dataweb.usitc.gov/.

[21] International Trade Center, "International trade map online database. Geneva: International Trade Centre UNCTAD/WTO (ITC)," 2009, http://www.trademap.org/.

[22] GAFI (General Authority for Investment and Free Zones), GAFI Information Center, General Authority for Investment and Free Zones, Cairo, Egypt, 2008.

[23] World Bank, Doing Business 2010, World Bank, Washington, DC, USA, 2009.

[24] D. Magder, "Egypt after the multi-fiber agreement: global apparel and textile supply chains as a route for industrial upgrading," Working Paper \# 05-8, The Institute for International Economics, Washington, DC, USA, 2005.

[25] World Bank, Doing Business 2009, World Bank, Washington, DC, USA, 2008.

[26] J. Chaponniére, Les Enjeux Economiques du Transport Maritime en Méditerranée, Fiche de Synthése DREE, Paris, France, 2002.

[27] World Economic Forum, Global Competitiveness Report 20092010, World Economic Forum, Geneva, Switzerland, 2009.

[28] A. El-Haddad, "Dispute resolution mechanisms in the Egyptian garment industry," Economics Letters, vol. 99, no. 3, pp. 425-430, 2008.

[29] CAPMAS (Central Agency for Public Mobilization and Support), "CAPMAS online database. Cairo: Central Agency for
Public Mobilization and Support," 2009, http://www.capmas .gov.eg/database.aspx.

[30] N. El Ehwany and N. El-Megharbel, "Employment intensity of growth in Egypt with a focus on manufacturing industries," Egyptian Center for Economic Studies (ECES) Working Paper Series \# 130, Egyptian Center for Economic Studies (ECES), Cairo, Egypt, 2009.

[31] Center for Trade Union and Workers Services, Impact of the Global Financial Crisis on Egyptian workers, Center for Trade Union and Workers Services, Cairo, Egypt, 2009.

[32] H. Handoussa, "Egypt and confrontation the international financial crisis effects: reading in the social and economic policy requirements," in The Social Effects of the International Financial Crisis on the Egyptian Economy and Confronting it Conference, Cairo University, Giza, Egypt, April 2009.

[33] N. El Ehwany, "Employment in Egypt: The impact of the global crisis on employment in light of labor market distortions," Egyptian Center for Economic Studies (ECES) Policy Viewpoint Series \# 23, Egyptian Center for Economic Studies (ECES), Cairo, Egypt, 2009.

[34] D. Schmidt, "National action plan for youth employment in response to the crisis," in Mitigating the Impact on the Global Economic Crisis on Egypt's Economy and Labour Market, International Labour Organization, Cairo, Egypt, December 2009.

[35] M. Sandler, Expanding Egypt's export opportunities through GSP, Office of the United States Trade Representatives (USTR), Washington, DC, USA, 2008.

[36] American Chamber of Commerce in Egypt, "Overall assessment of selected apparel manufacturing factories," in Conference on Improving Labour Productivity in Egypt's Ready-Made Garment Sector, American Chamber of Commerce, Cairo, Egypt, April 2009.

[37] J. Beinin, "Popular social movements and the future of Egyptian politics," 2005, http://www.merip.org/mero/mero031005.html.

[38] J. Beinin and H. El-Hamalawy, "Strikes in Egypt spread from center of gravity," 2007, http://www.merip.org/mero/ mero050907.html.

[39] G. Ragaay, "A report on workers in the textile and clothing sector," Social and Economic Rights Series \# 63, Earth Center for Human Rights, Cairo, Egypt, 2008.

[40] A. El-Haddad, "Labor market gender discrimination under structural adjustment: the case of Egypt," Working Paper Series \#003, American University in Cairo, Social Research Center, Cairo, Egypt, 2009.

[41] Public Enterprise Sector Information Center, Financial and Economic Indicators, Public Enterprise Sector Information Center, Cairo, Egypt, 2007/2008.

[42] Public Enterprise Sector Information Center, Financial and Economic Indicators, Public Enterprise Sector Information Center, Cairo, Egypt, 2008/2009.

[43] Ministry of Investment, Ministry of Investment Unpublished Database, Ministry of Investment, Cairo, Egypt, 2009.

[44] L. Hassan, Hanging by a Thread, Business Today Egypt, 2010.

[45] A. El-Haddad, "Egypt versus South Korea: divergent paths to industrialization," in Role of the State in a Mixed Economy, A. Shehata, Ed., Partners in Development (PID), Cairo, Egypt, 2010.

[46] Ministry of Trade and Industry, "Trade agreements sector: Trade monitoring. Cairo: Ministry of Trade and Industry," 2008, http://www.tas.gov.eg/English/Trade\%20Monitoring/ tmc_Guides/tmc_Guides. 
[47] H. Kheir-El-Din and A. Ghoneim, "The economic and regulatory policy implications of overlapping preferential trade agreements in the Arab countries: the case of Egypt," Research Report Series 0425, Economic Research Forum (ERF), IDRC Research Programme, Cairo, Egypt, 2005.

[48] Ministry of Trade and Industry, "Qualifying industrial zones. Cairo: Ministry of Trade and Industry: QIZ Unit," 2008, http://www.qizegypt.gov.eg/About_FAQ.aspx.

[49] Institute of National Planning, The Egyptian Economy between Growth Opportunities and Current Challenges, Institute of National Planning, Cairo, Egypt, 2006.

[50] M. Zeitoon, Implications of the Global Financial Crisis on the Tourism Sector in Egypt, International Labor Organization, Cairo, Egypt.

[51] Egyptian National Competitiveness Council, Beyond the Financial Crisis: Competitive and Sustainable Development, Egyptian National Competitiveness Council, Cairo, Egypt, 2009.

[52] M. Agroody, "Emergency subsidies for 3134 workers in troubled companies," Al-Ahram Newspaper, 27-January 2010.

[53] S. M. Thangavelu and M. H. Toh, "Bilateral 'WTO-plus' free trade agreements: the WTO trade policy review of Singapore 2004," World Economy, vol. 28, no. 9, pp. 1211-1228, 2005.

[54] A. El-Haddad, "The GSP brochure. Cairo: Ministry of Trade and Industry," 2008, http://www.tas.gov.eg/Arabic/Trade\% 20Agreements/agreements/.

[55] A. Refaat, "Assessing the impact of the QIZ protocol on Egypt's textile and clothing industry," Egyptian Center for Economic Studies (ECES) Working Paper \# 113, Egyptian Center for Economic Studies (ECES), Cairo, Egypt, 2006. 


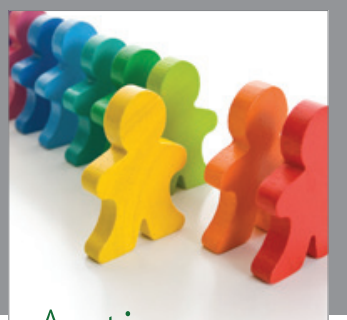

Autism

Research and Treatment
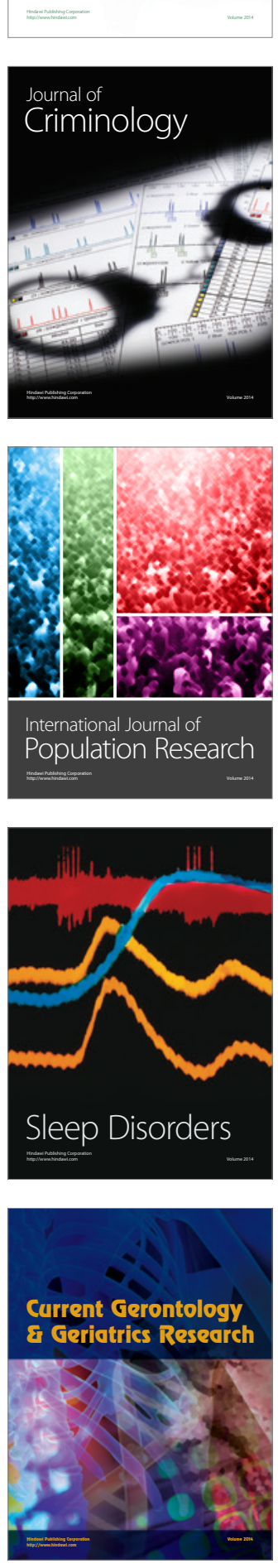
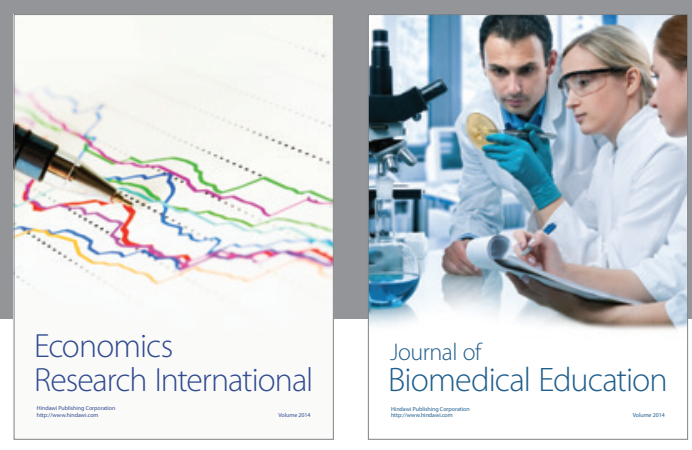

Journal of

Biomedical Education

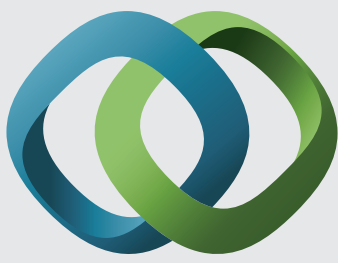

\section{Hindawi}

Submit your manuscripts at

http://www.hindawi.com
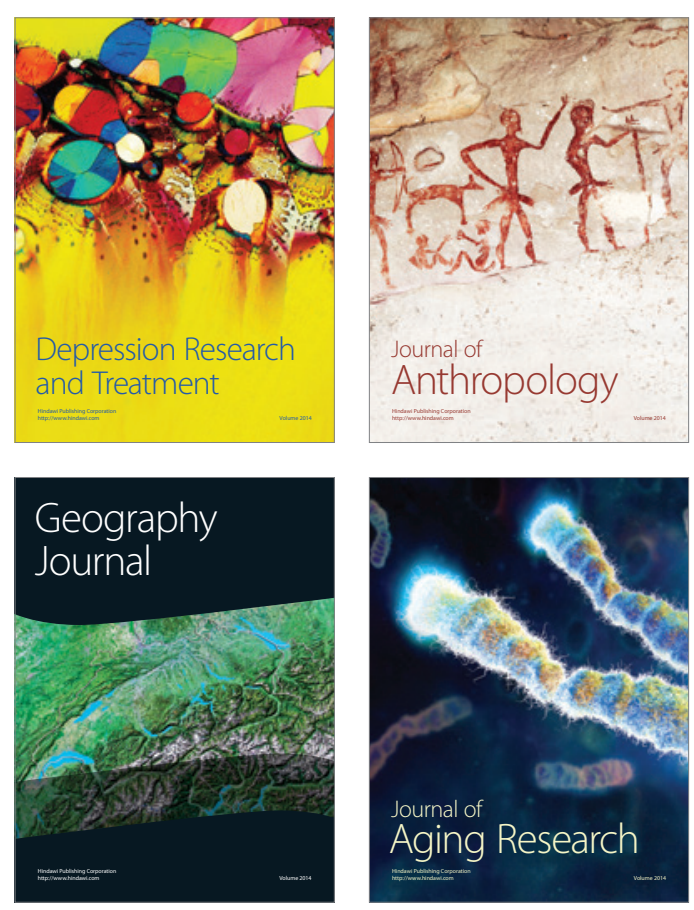

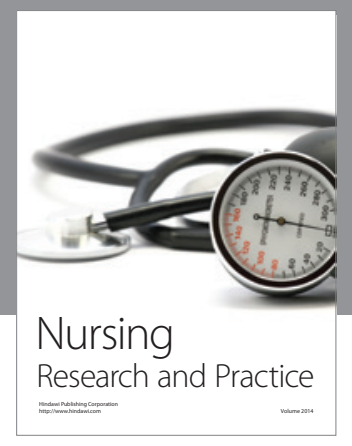

Nursing

Research and Practice

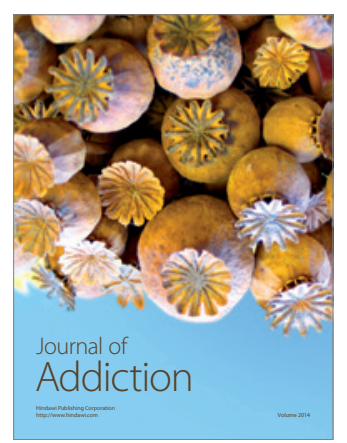

Child Development

Research

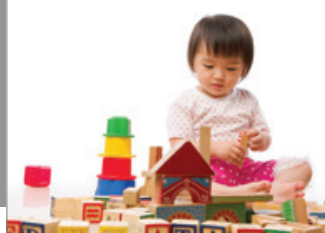

迥
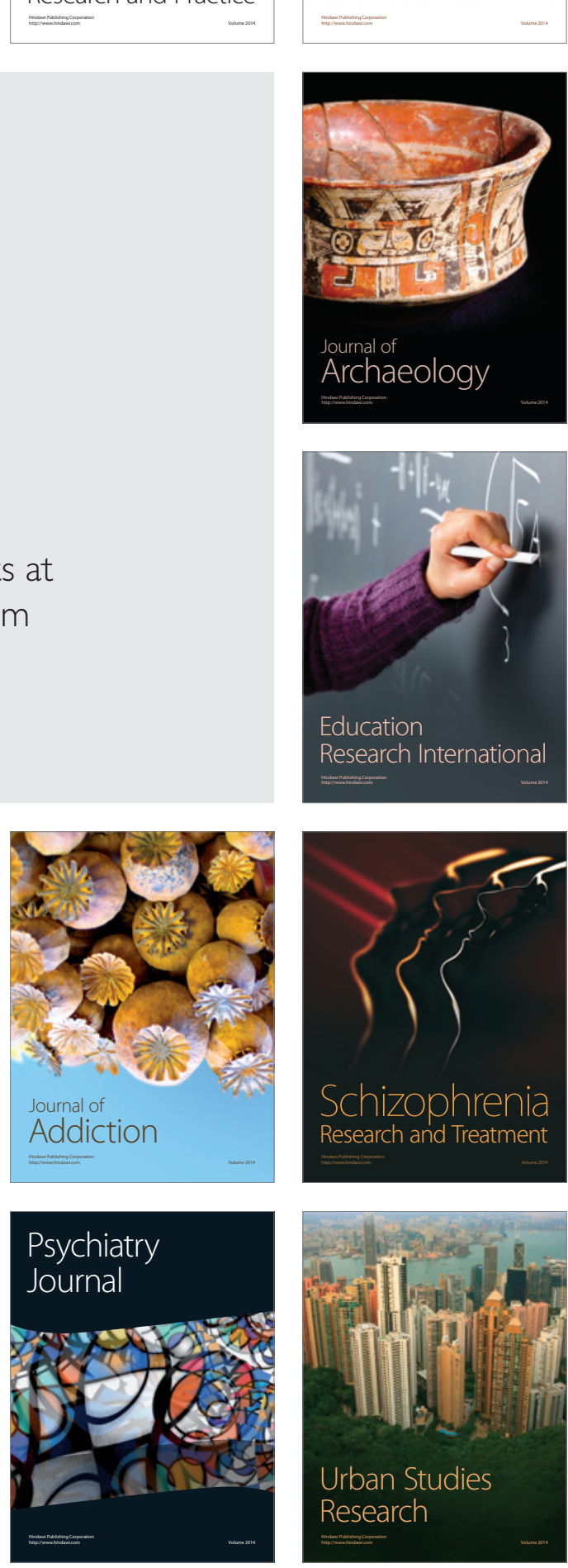